\title{
3 Implementation of Resource Conservation Policies in the Norwegian Fisheries: A Historical Outline
}

\author{
Stig S. Gezelius
}

\begin{abstract}
This chapter presents the history of Norwegian fisheries management since 1900, focusing on the system for implementing resource conservation goals. It describes how the Norwegian implementation system has developed incrementally in response to new implementation challenges and outlines in detail the system for handling the most difficult legal and administrative issues in TAC-based management. The chapter seeks to explain the continuity and incremental growth of the Norwegian implementation system, as well as the role of fishing industry organisations in developing it. It argues that the nature of the development of the Norwegian implementation system has been shaped by Norway's level of national autonomy in fisheries management, the division of authority between the Parliament and the fisheries administration, and the power relationship between the fisheries administration and the key industry organisations.
\end{abstract}

\subsection{The Subject and the Actors}

This chapter describes the historical development of the Norwegian system for implementing Total Allowable Catches (TACs). The focus is on resource conservation, meaning that the much-discussed question of allocation is addressed only to the extent that it is directly relevant to the implementation of conservation targets. The chapter describes the essential features of the Norwegian system for implementing TACs and offers explanations for how these features developed. An important characteristic of the Norwegian implementation system, influencing this chapter's descriptive approach, is that it has developed through incremental changes to regulatory details rather than through a large general plan. Consequently, the fundamental ideas of the implementation system must be sought after in regulatory details that may appear to be insignificant at first glance, especially to readers who are unfamiliar with fisheries management. The incremental nature of this development has meant that solutions for the present have largely been built upon the structures of the past. Consequently, understanding the specifics of 
the Norwegian implementation system requires delving into the historical development of the structures that that eventually shaped it. A major goal of this chapter is thus to link regulatory specifics to the ideas and structural conditions that shaped them. Explaining regulatory detail in the light of their structural conditions implies a historical approach to the implementation system. Catch quotas were introduced in Norwegian fisheries management in the early 1970s, but beginning this outline at that point would lead us to ignore some fundamental conditions that have shaped the implementation system. Consequently, this chapter begins with a description of certain important pre-WWII events that later became crucial to the implementation of TACs in Norway.

This chapter is motivated by the lack of systematic and explanatory descriptions of the Norwegian system for implementing TACs in relation to resource conservation. However, there is rich literature covering a number of other significant aspects of Norwegian fishing and fisheries management, also for English readers. Consequently, I do not give a general descriptive introduction to the Norwegian fishing industry. Readers looking for such a background can easily find this elsewhere. ${ }^{1}$ I will limit the introductory background to a brief presentation of the main actors that have shaped the development of the implementation system and the basic relationships between them.

The incremental nature of the development of the Norwegian implementation system is a result of practically-oriented management. The development of the Norwegian implementation system has above all focused on solving specific problems at the practical level. This is reflective of the fact that the practitioners of fisheries management (the fisheries administration) and the regulated actors (the fishing industry) have been the key actors in this process. Four central actors have shaped the development of the Norwegian system for TAC implementation: the Ministry of Fisheries and Coastal Affairs (which I will mostly refer to as the Ministry of Fisheries ${ }^{2}$ ), the Directorate of Fisheries, the Norwegian Fishermen's Association, and the fishermen's sales organisations.

The Ministry of Fisheries and Coastal Affairs, headed by the Minister of Fisheries, is located in Oslo and has overall administrative responsibility for fisheries management. It draws up general fisheries policies and proposed laws, and is responsible for implementing fisheries legislation. Today's fisheries legislation mostly consists of enabling acts giving the Ministry of Fisheries and Coastal

\footnotetext{
${ }^{1}$ For a general introduction to the Norwegian fisheries in English, see Hersoug 2005. Hersoug's book also gives a thorough outline of the allocation aspect of Norwegian fisheries management. General descriptions in English of industry, industry organisations, and management can also be found in, for example, Apostle et al. 1998, Gezelius 2003, and Hallenstvedt 1995. For Norwegian readers, specialised historical descriptions have been given of the Directorate of Fisheries (Nordstrand 2000) and the fishing industry organisations (Christensen \& Hallenstvedt 1990, 2005; Hallenstvedt \& Dynna 1976; Johannesen \& Misje 2002).

2 The Ministry of Fisheries changed its name into Ministry of Fisheries and Coastal Affairs in 2004. I will mostly refer to it as the "Ministry of Fisheries" because that was its name through most of the period described in this chapter.
} 
Affairs extensive authority in terms of regulating the fisheries. The Ministry of Fisheries and Coastal Affairs currently employs a staff of approximately 110 people. However, the Ministry is not the centre of implementation of conservation policies. This centre is constituted by the Directorate of Fisheries, which is organised as a separate unit under the Ministry of Fisheries and Coastal Affairs and located in Bergen. The Directorate of Fisheries is the executive and advisory unit of the Ministry of Fisheries and Coastal Affairs. It is responsible for the day-to-day regulation of the fisheries, issuing more than 250 regulations per year. It also has the main responsibility for the enforcement of fisheries regulations, and provides advisory services for the fishing industry. In addition to its central office in Bergen, it has a number of regional and local offices fulfilling enforcement and advisory tasks along the coast. The Directorate of Fisheries presently has a staff of approximately 450 people, 250 of whom work in regional or local offices.

The Norwegian Fishermen's Association is the main industry organisation representing the interests of fishermen. It includes inshore fishermen, offshore fishermen, vessel owners, and crews throughout Norway. After the offshore sector joined the Norwegian Fishermen's Association in the 1960s, the Norwegian Fishermen's Association has had a virtual monopoly on representing the interests of fishermen. ${ }^{3}$ The organisation has strong influence on Norwegian fisheries politics and is formally and informally consulted by the Ministry of Fisheries and Coastal Affairs and the Directorate of Fisheries on all significant matters. The fisheries administration has treated the Norwegian Fishermen's Association as the main voice of the fish harvesting industry and included it in decision-making to the extent that it has emerged as the government's fisheries management partner. The Ministry of Fisheries and Coastal Affairs and the Directorate of Fisheries have considered the dominant position of the Norwegian Fishermen's Association to be a significant advantage because it reduces the heterogeneity of industry advice (Gezelius 2002a, 2003; Christensen and Hallenstvedt 2005). While the Norwegian Fishermen's Association voices the interests of fishermen in relation to political and administrative agencies, the fishermen's sales organisations protect the fishermen's interests in the market. There are five sales organisations for groundfish, each one covering a specific geographical area. In addition, there is one sales organisation for pelagic fish in all of Norway. The sales organisations are owned by fishermen and have law-protected monopolies in their respective areas regarding the purchase of fish from fishermen. These monopolies imply that fishermen are only allowed to sell their fish through a fishermen's sales organisation. In practice, the fishermen sell their catch to private fish buyers who operate under the instructions of the sales organisations and act on their behalf when dealing with the fisherman. The sales organisations were established to give the fishermen control over

\footnotetext{
${ }^{3}$ The Norwegian Coastal Fishermen's Association was established in 1987 in response to the influence of the offshore interests on the Norwegian Fishermen's Association. Although the Norwegian Coastal Fishermen's Association gradually has become accepted as a legitimate industry voice, it has never managed to threaten the dominant political position of the Norwegian Fishermen's Association.
} 
fish prices ${ }^{4}$ and to secure payment for their catch. Although they were established for the purpose of market regulation, the sales organisations have to an increasing extent been instructed to undertake tasks related to the implementation of government policies. The sales organisations constitute a centralised structure for handling the data and money-flow relating to the first-hand trade of fish. Consequently, they have become important actors in the Norwegian system for TAC implementation.

A large share of the data for this chapter have been generated from government documents, mainly acts, regulations and preparatory papers covering Norwegian fisheries management throughout the 20th and 21 st centuries. Important data have also been drawn from previously published studies largely based on fieldwork among fishermen and interviews with key informants in the fisheries administration, the Coast Guard, the Norwegian Fishermen's Association and the sales organisations (Gezelius 2002a, 2003, 2006, 2007a). The key informants in these studies were selected on the basis of their positions and work tasks and were generally offered anonymity. More thorough descriptions of methodology can be found in the cited publications. These data have been supplemented with ad hoc personal communication with management personnel regarding specific issues during the writing of this paper, as indicated in citations. Needless to say, the works of a number of other authors, cited in the regular manner, have been of great value.

\subsection{5-1977: From Industry Development to Resource Management}

\subsubsection{Preconditions Developed Before 1945}

The end of World War II opened a period of increasing fishing capacity and expansion of the Norwegian state apparatus, which makes it a natural starting point for an outline of the construction of modern fisheries management in Norway. However, several institutions that were built before WWII facilitated the post-war development. When the Ministry of Fisheries was established in 1946, a fisheries administration had been in place under various other ministries for almost 50 years. The late 1800 s and early 1900 s saw an expansion of the use of engines in the Norwegian fishing fleet, allowing fishermen to use more efficient gear than in previous years. This development triggered a need for management and

\footnotetext{
${ }^{4}$ The sales organisations set minimum prices for fish based on market analyses. Minimum prices are set following negotiations with the fish buyers' organisation, but the sales organisations are authorised to set prices when an agreement cannot be reached.
} 
knowledge of marine fish stocks. Consequently, the Directorate of Fisheries, which is organised under the Ministry of Fisheries and Coastal Affairs, and is responsible for enforcement and technical aspects of fisheries management today, was established in 1900 under the name The Fisheries Board (Fiskeristyrelsen). The Directorate of Fisheries was constructed at the same time as the International Council for the Exploration of the Sea (ICES), and development of marine science became one of the core tasks of the young Norwegian fisheries administration. The fact that the Director of Fisheries discovered the significance of year classes to the periodic changes in the fisheries, which is a cornerstone in modern TACbased management, illustrates the strong connection between science and management in this period. The marine biologist Johan Hjort was Director of Fisheries from 1906 to 1916, and made his seminal discovery in 1913.

Apart from fisheries science, the early tasks also included fishing industry development and administration of fisheries law. The Directorate of Fisheries established a quality control for fish in 1903, which was the beginning of a control system that developed into today's enforcement of catch quotas. The Act on Tagging and Registration of Fishing Vessels was decided upon in $1917^{5}$ and implemented beginning in 1920 (Government of Norway 1917; Nordstrand 2000). The early regulatory responses to the modernisation of the Norwegian fisheries in the late 19 th and early 20th century mainly aimed to solve or reduce conflicts between the users of different gear types, but also included some pure conservation measures for lobster, salmon, and marine mammals (Hallenstvedt \& Dynna 1976; Nordstrand 2000).

Perhaps of greatest consequence for the government's future capacity to implement resource management policies was the organisation of the fishing industry that took place during the inter-war years. This organisation process reflected and created tight and enduring connections between the fishing industry and the state. The organisation of the first hand trade of fish was to become especially important to implementation. Economics hardships in the fishing industry during the 1920s generated attempts by fishermen to organise the first hand trade of fish, which led to the establishment of the first fishermen's sales organisation in 1927. The fishermen fought for law protection of their sales organisations, which eventually led the establishment of the Raw Fish Act in 1938 (Christensen \& Hallenstvedt 1990; Johannesen \& Misje 2002). A new version of this was established in $1951^{6}$ and is still in effect. The Raw Fish Act ensures the fishermen's sales organisations a lawprotected monopoly on first-hand trade of fish. Consequently, fishermen can only land fish to buyers that operate through sales organisations, and all fish buyers must act according to the rules of these sales organisations. In practice, the buyer acts on behalf of the sales organisation when dealing with the fisherman. When receiving catch from the fisherman, the buyer sends sales notes to the sales organisation, which subsequently pays the fisherman. This system has entailed that all

\footnotetext{
${ }^{5}$ In Norwegian, this act was called Lov om registrering og merking av fiskefartøyer.

${ }^{6}$ In Norwegian, this act is called Lov om omsetning av råfisk (Råfiskloven).
} 
fish landings are traded through a centralised system of law-protected organisations which are required to report catch statistics to the Directorate of Fisheries (Nordstrand 2000: 177). The purpose of the Raw Fish Act was to enhance the market position of fishers, granting them control over fish prices and securing their payment. However, the organisation of first-hand trade of catch has greatly facilitated the monitoring of fishing mortality, and became an important factor in the implementation of the Norwegian resource management system that began to evolve some 40 years later.

Another significant development was the founding of the Norwegian Fishermen's Association. The Norwegian fish harvesting industry had traditionally been organised in several local organisations at the county level. However, the government, which wanted to consult a unitary fish harvesting industry, initiated a process leading to the merging of the local organisations into the Norwegian Fishermen's Association in 1926. By the early 1970s, this organisation represented the entire fish harvesting industry, including owners and crew in both inshore and offshore fisheries (Hallenstvedt \& Dynna 1976). The Norwegian Fishermen's Association has demonstrated a remarkable capacity to arbitrate between conflicting industry interests and, by so doing, present uniform advice to the government. Consequently, the Norwegian Fishermen's Association has become indispensable to the government in terms of handling the distributional issues that accompany modern TAC-based management. It has significant influence on governmental harvesting regulations. It also has a significant role in implementation by communicating regulations back to the industry. It will be argued that the role of the Norwegian Fishermen's Association has made implementation of fish harvesting regulations much easier for the state by improving state/industry communication and increasing the legitimacy of state policies.

\subsubsection{Early Post-war Policies}

As described in Chapter 2, questions of overfishing and resource conservation attained increasing attention in the international fisheries commissions during the first decades after World War II, and the need to restrict fishing capacity and/or regulate catch quantities became generally recognised among the contracting parties. The attempts to coordinate conservation efforts in the Atlantic fisheries commissions emerged in response to modernisation efforts at the national level. Therefore, the development in fisheries management at the international level moved, in some respects, in the opposite direction of the policies at the national level. While the need to reduce fishing pressure received increasing attention, also from Norwegian managers, in the North Atlantic fisheries commissions from the late 1950s, the Norwegian domestic fisheries policies continued to focus mainly on modernising the fishing industry. This policy was driven by the belief that the traditional combination of farming and seasonal inshore fishing was economically inefficient, 
and that future demands for profitability and a stable supply of fish required developing a Norwegian offshore trawl fishery (Government of Norway 1957a).

The introduction of freezer technology represented an opportunity for the Norwegian fish processing industry, which was located far from its export markets, to export fresh products and to rationalise traditional conservation methods. Consequently, the government initiated and promoted the development of freezer plants, a number of which were built during the 1950s. The new freezer plants depended on stable access to fish landings, which became an important motivation for government policies encouraging the development of the trawl fishery. The Norwegian fishing fleet was owned by fishermen, which meant that there had not been enough concentrated capital to develop a significant trawl fishery. Neither was there any great interest in the industry for building or buying trawlers. Consequently, the government actively promoted the expansion of the trawler fleet by softening up the traditional licensing policy that had only allowed fishermen to own fishing vessels, offering loans, and initiating test fisheries. With these policies in place, the trawler fleet expanded throughout the 1960 s, contributing to a growing political concern about overcapacity (Hersoug 2005; Holm 1996; Nordstrand 2000: 300-316).

In the early post-war years, Norwegian fishermen harvested from stocks that were in good conditions due to the pause in fishing caused by the war. Consequently, overfishing was not a major concern in the early days of these modernisation programmes. Norway had attended the international fishery conferences of the 1930s and 1940s and signed the agreements. However, it was among those states that were resistant to regulatory restrictions on fishing, as it saw the requests for such regimes largely as attempts by other states to gain increased control of fisheries resources. None the less, reports from British scientists warning about overfishing in the North Sea brought the attention of Norway's fisheries administration to the issue.

The question of overfishing started to become a genuine concern among Norwegian fishery managers in the late 1950s and gradually turned Norway into a supporter of stricter regulation during the following decade. However, this growing concern was not initially manifest in domestic politics because national control of fishery resources was practically non-existent at the time. The North Atlantic fisheries commissions were the main arena for conservation policies. In the late 1950 s, Norway voiced the need for stricter management of the arctic cod stock in the Permanent Commission. ${ }^{7}$ In a speech held in 1964, the Director of fisheries recognised that conservation of fish stocks had become the main question for many fisheries in the North Atlantic, and strongly supported the development towards stricter regulatory measures that had just began in ICNAF. ${ }^{8}$ He expressed

\footnotetext{
${ }^{7}$ The Permanent Commission was the forerunner of the North East Atlantic Fisheries Commission (NEAFC). A closer description of these institutions has been given in Chapter 2.

${ }^{8}$ The International Commission for the Northwest Atlantic Fisheries (ICNAF) was the forerunner of the Northwest Atlantic Fisheries Organization (NAFO).
} 
his belief that management in the form of catch quotas was the most desirable outcome of this process (Government of Norway 1975a; Sunnanå 1964). The concern about resource conservation continued to increase from then on.

The national policy to increase Norway's fishing capacity can thus be regarded as a combination of two mechanisms. On the one hand, it was a rational adaptation to a prisoner's dilemma situation created by more or less open access to fishery resources beyond territorial waters during the first couple of decades after WWII. On the other hand, and perhaps more importantly, it was a result of political priorities that had been made when resource conservation only had a marginal place on the agenda. The inertia of these principal political priorities entailed that it took time before concerns about overfishing influenced fisheries policies significantly. While Norwegian fisheries policy was mainly oriented towards industry development in the 1950s and 1960s, it addressed resource conservation to an increasing extent from the 1970s (Nordstrand 2000). In the early 1970s, the question of catch quotas and fishing effort had become dominating on the agendas of the international fisheries commissions, and the question of overfishing had become a major concern for fisheries managers.

\subsubsection{The Development of a Legal Framework for Fisheries Management}

Norwegian fisheries law had traditionally been a fragmented set of region- and species-specific acts. Work to gather the fragmented fisheries legislation into unified national laws began in the 1930s. Several laws on pelagic fisheries were replaced by the Herring and Sprat Fisheries Act in 1937. ${ }^{9}$ This act focused almost entirely on detailed arrangements to solve and avoid various types of user conflicts on the fishing grounds, which had grown more intense following the introduction of the purse seine and motors in the fishing fleet. Article 37 contained regulations on closed areas and seasons and minimum size of fish, but these regulations were mainly motivated by quality and marketing rather than conservation (Government of Norway 1937a, b). In 1939, the government started to work on similar simplifications for the remaining fisheries. This work was unfinished when the war came, and was resumed in 1947. At that time, the fish harvesting practices of Norwegian fishermen were still managed through more than twenty different laws.

Several regional fisheries laws had been established from the 17th century to avoid gear conflicts and to ensure order on the cod fishing grounds. From the late 19th century, these were accompanied by national laws aimed to meet conservation challenges following technical modernisation. Legislation regulating the use of potentially-harmful gear types in saltwater fisheries developed gradually. A prohibition of the use of explosives in fishing came in place in 1911. An act from

\footnotetext{
${ }^{9}$ In Norwegian, this act was called Lov om sild- og brislingfiskeriene.
} 
1914 restricted the use of certain gear types, and authorised the government to use small-fish regulations. Acts concerning minimum sizes of plaice and halibut were passed in the 1930s. Following the 1937 London fisheries conference regarding mesh sizes and minimum fish sizes in demersal fisheries, a new Act on Preservation of Salt Water Fish ${ }^{10}$ was created that adopted standards set at the London Conference and merged several previous acts concerning gear restrictions and small-fish regulations (Government of Norway 1938, 1954). A separate act on the conservation of lobster had also been established since 1923.

The work to create a more surveyable and unified legal framework eventually led to the creation of the Salt Water Fishing Act of $1955,{ }^{11}$ which mainly applied to the demersal fisheries (Government of Norway 1954, 1955). This act adopted its basic framework from the Herring- and Sprat Fisheries Act, and concentrated mainly on regulation of potential user conflicts. However, Article 4 of the 1955 Saltwater Fishing Act also included the conservation measures of previous legislation concerning harmful fishing gear. As an adaptation to the ICNAF Convention in 1949, which Norway had signed, Article 4 also authorised the Ministry of Fisheries to set catch quotas for the purpose of conserving fish stocks or complying with international agreements. The provision for catch quotas did not reflect the Norwegian political agenda of the day. Serious discussions on how to restrict fishing pressure had not yet begun. The fundamental discussion on quotas and effort regulations took place in the Atlantic fisheries commissions during the following fifteen years. In that respect, the provision for catch quotas in the ICNAF convention and the Saltwater Fishing Act of 1955 were ahead of the political processes that led to their implementation.

While previous legislation outlined the specific conservation rules to be observed in fishing, the Saltwater Fishing Act of 1955 used an enabling article that authorised the Ministry of Fisheries to apply a defined set of conservation methods and to define the detailed content of conservation rules (Government of Norway 1954, 1955). Over the following decades, delegation of this authority became the general mode of managing Norwegian fisheries. Consequently, fisheries regulations set by the fisheries administration became the legal tool used for detailed management of fishery resources. The content of Article 4 in the Saltwater fishing act was included in the Herring and sprat fisheries act through an amendment in 1957, extending the same authority into these fisheries (Government of Norway 1957b).

The 1950s also saw the development of the first general legal framework to regulate access to the fisheries. Since 1917, all vessels used for the purpose of commercial fishing had been required to be marked and included in a national register of fishing vessels. The 1917 act implied no restrictions on access to the fisheries as such, but became an important tool in the implementation of future access restrictions. Trawl fishing required a licence from the Ministry of Fisheries

\footnotetext{
${ }^{10}$ In Norwegian, this act was called Lov om fredning av saltvannsfisk (6 May 1938).

${ }^{11}$ In Norwegian, this act was called Lov om saltvannsfiskeriene.
} 
following a special Act on Trawl Fisheries from 1951' (Government of Norway 1951b), but the first general legal step in the direction of access restrictions in fishing was the preliminary act of 1956 on the right to own fishing vessels (Government of Norway 1956). This act stated that a license from the Ministry of Fisheries was required in order to acquire ownership of a registered fishing vessel or to register a new vessel. No unregistered vessel could legally be used for commercial fishing. In practice, the access policy was not notably restrictive: government regulations allowed vessels under 50 feet to be included in the register without a specific permission, and individuals and companies fulfilling the law's requirement of at least three years of fishing as their main occupation were allowed to register and fish with their vessels. However, this legislation became the basis for more restrictive policies when crisis struck the herring fisheries in the late 1960s. The herring crisis resulted in an amendment to the preliminary act of 1956 authorising the Ministry of fisheries to cease registering new vessels. The Ministry began to use this new power in 1970, when it stopped registering new purse seiners (Government of Norway 1992: 27).

As we have seen, political concern about overcapacity and overfishing emerged during the 1960s. The government, which had actively promoted modernisation of the fishing fleet, began to worry about the consequences of unregulated expansion of new efficient fishing methods. The discourse in the Atlantic fisheries commissions on new management measures, described in Chapter 2, was followed by a perceived need to improve the legal tools for controlling input into the fishery. Consequently, a new enabling Act on Regulation of Participation in the Fisheries (Participation $\mathrm{Act}^{13}$ ) was passed in 1972, replacing the preliminary act from 1956. This act increased the possibilities for the Ministry of Fisheries to control expansion of the fishing fleet for the purpose of conservation or rational utilisation of fish stocks, as well as its authority to give dispensation from the legal requirements for registration. In addition to the system of general fishing licences, the new act authorised the government to regulate access to each specific fishery through licensing schemes, and to require that fishermen obtain government permission before they could modify fishing vessels significantly. It also authorised the Ministry of fisheries to set catch quotas and to distribute these among the fishermen. Consequently, the halt in registering new purse seiners, which had been introduced in 1970, was replaced by a licensing scheme in 1973 (Government of Norway 1971a, 1972a, 1992).

The Participation Act represented a national adaptation to the ongoing regulatory processes in the North Atlantic fisheries commissions. However, it appears that the influence on Norwegian legislation of the discourses in ICNAF and NEAFC went beyond merely required legal adaptations. In effect, the 1972 Participation Act authorised the government to implement the management principles recommended by the ICNAF Working Group on Joint Biological and Economic

\footnotetext{
12 In Norwegian this act is called Lov om fiske med trål.

${ }^{13}$ In Norwegian, this act is called Lov om regulering av deltakelsen i fiske (Deltakerloven).
} 
Assessment of Conservation Actions in 1967: resource conservation through catch quotas, supplemented by limited entry licensing for the purpose of economic efficiency. ${ }^{14}$

The Participation Act continued the development of the corporatist management model that has been typical of the administration of the fisheries, as well as other Norwegian industries. The Norwegian Fishermen's Association was concerned about the ability of the industry to adapt to forthcoming policy changes and began deliberations regarding regulation procedures with the fisheries administration in 1970 (Christensen and Hallenstvedt 2005: 235). These deliberations eventually led to the establishment of two advisory councils. Articles 7 and 10 of the Participation Act of 1972 established that licensing schemes for specific fisheries, catch quotas, and distribution of these quotas could only be decided after consultations with a board of representatives from the fishermen's unions. The Licensing Committee, which consisted of representatives from government and industry (four out of eight members were from the Norwegian Fishermen's Association), was established in 1972 for the purpose of counselling the government on these issues. A specific Regulatory Committee, consisting of representatives from the fishing industry, science and government, to advise the Ministry of Fisheries on resource management issues followed in 1973 (Hoel et al. 1991; Government of Norway 1981a; Nordstrand 2000).

Catch quota-based management emerged gradually in Norwegian fisheries management beginning in 1970 . This policy reform was by no means unilateral. As outlined in Chapter 2, the use of TACs followed directly from negotiations that had taken place in the North Atlantic fisheries commissions since the mid-1960s. These negotiations had been generated by increasing concern about capacity increase and overfishing on both sides of the North Atlantic, but especially within ICNAF which was the leading arena for the introduction of TACs. However, by the late 1960s, the severe concerns about the fish stocks in the Northwest Atlantic had been accompanied by a crisis in the Northeast Atlantic fisheries: the collapse of the Atlanto-Scandian herring stock in 1968/69. The catches of North Sea herring was also in decline. The crisis in the herring fisheries created a severe problem of overcapacity in the pelagic fishing fleet and an ensuing need for managing the pelagic fisheries in the region (Hersoug 2005; Rozwadowski 2002: 178-182). The states that were most dependent on the Atlanto-Scandian herring were unwilling to wait for agreement within NEAFC and, consequently, established the first catch quotas outside the NEAFC framework. Consequently, the Norwegian Ministry of Fisheries set a quota for mackerel fished for fishmeal and oil in 1970 (Government of Norway 1970). Following an agreement between Norway, Iceland, and the USSR, a regular TAC for Atlanto-Scandian herring was established for 1971 (Government of Norway 1971b; NEAFC 1971). A catch quota for capelin was set for 1972 (Government of Norway 1972b).

\footnotetext{
${ }^{14}$ This ICNAF working group has been described in Chapter 2.
} 
The emergence of TAC-based management soon raised questions of distribution and efficient utilisation of quotas, and resulted in industry demands for vessel quotas. ${ }^{15}$ Discussions about the use of vessel quotas began as early as 1972, and reflected concern about inadequate legal tools for implementation. Initially, the Ministry of Fisheries was reluctant to introduce vessel quotas because existent law only addressed illegal catch in relation to punishable acts, meaning that catch exceeding quotas could only be confiscated after prosecution and subsequent court decision (Government of Norway 1976c). However, due to pressure from the industry, vessel quotas were applied in the capelin fisheries in 1973-74, and later also in herring and mackerel fisheries, without legal provisions for non-penal confiscation of catch. The early experiences with vessel quotas made clear to managers that they needed a system for handling unintended exceeding of quotas. Discussions on how to handle this issue began in 1974 through dialogue between the Ministry of Fisheries, Directorate of Fisheries, and the major industry organisations. These discussions resulted in several amendments to the Participation Act in 1976, which gave the fishermen's sales organisations an important role in the implementation of the catch quota system. The Ministry of Fisheries could now authorise the sales organisations to estimate vessel quotas and the sales organisations became responsible for administrating catch exceeding these quotas. Catch exceeding a vessel quota would now be calculated and confiscated by the sales organisation, which also would keep the value of the catch, regardless of the fisherman's criminal liability.

A core question was whether confiscating catch from fishermen who were not liable to punishment was consistent with the Norwegian Constitution. This new provision for catch confiscation was based on the view that fishermen do not own catch that they are not legally permitted to take. Consequently, confiscation of illegal catch was not considered confiscation of private property and, thereby, not as penalty. It simply regulated the ownership to values that had no owner. Consequently, it was considered that such confiscation would not violate the Norwegian Constitution (Government of Norway 1976c).

The amendment enabling the sales organisations to confiscate catch regardless of the fisherman's criminal liability marked the beginning of a management practice that later was extended and became a key element in the Norwegian system for implementing TACs: non-penal confiscation of illegal catch. The amendment concerning catch confiscation was significant in two important ways. First, it established a system for the confiscation of catch as an administrative, non-penal, arrangement to handle the problem of catch incidentally exceeding quotas. Consequently, illegal catch could now be confiscated regardless of the ability of

\footnotetext{
${ }^{15}$ A vessel quota is a quota allocated to one specific vessel in contrast to, for example, a quota allocated to a group of vessels. Vessel quotas imply that each vessel is allocated a specific share of the TAC, which entails that it will not have to compete with other vessels in catching this share. Thereby, vessel quotas increase the predictability for fishermen and reduce the competitiveness of fishing. In Norwegian management, the term "vessels quota" is used instead of "individual quota" (IQ) because quotas are allocated to vessels rather than individuals.
} 
enforcement personnel to prove criminal negligence. The fact that landing illegal catch was not followed by penalty, such as fines or confiscation of the legal part of the catch, also reduced the incentives for discarding ${ }^{16}$ illegal catch. This reform also established a system for administration of the value of illegal catch. Discarding illegal catch was still mandatory according the Saltwater fishing act of 1955, but this new system facilitated a radical change of that policy, enabling implementation of the ban on discards that began to emerge ten years later. Notably, the desire to reduce discards became prevalent among policy makers at the time when these amendments to the Participation act were made (Government of Norway $1975 c ; 1976 c, d)$. Although it would take several years before the concern about discards resulted in a legal ban, the authorisation and preparation of the sales organisations to administer landings of illegal incidental catch became a central condition for the implementation of this ban later. Second, the amendments meant that the implementation of catch quotas had become a joint state/industry endeavour. It marked a significant expansion of the role of the law-protected fishermen's sales organisations. Originally, their task was to secure a strong market position for the fishermen through monopolies on first hand trade. With the introduction of catch quotas, this centralised system became a handy instrument in resource management and made the fishing industry a responsible partner in the new resource management regime.

Disillusionment regarding the capacity of international commissions to effectively regulate fisheries contributed to the breakthrough of the principle of 200 nautical miles Exclusive Economic Zones (EEZs) at the third session of the United Nations Conference on the Law of the Sea in 1975. The basic idea was that the coastal states were given the right to manage and utilise the resources within exclusive zones stretching 200-nautical miles off shore, which roughly covered the states' continental shelves. This exclusive right included setting TACs and distributing them. The Act on Norway's Economic Zone was passed in December 1976, and the EEZ was established from January 1977. This act was nothing short of a revolution in terms of national control of fishery resources. By comparison, Norway's control over fisheries had been limited to the $4 \mathrm{~nm}$ territorial sea until 1961 when Norway established its 12 nm Fishing Zone (Government of Norway 1976b, 2003d). The Act on Norway's Economic Zone gave Norwegian citizens the exclusive right to utilise marine living resources, and authorised the Ministry of fisheries to regulate catch quotas, fishing effort, and the access of foreign fishermen within an exclusive zone of 200 nautical miles covering most of the continental shelf. On the other hand, the government believed that an adequate legal framework for fisheries management was already in place, and the act establishing the EEZ introduced nothing new in terms of the state's authority to manage fisheries apart from extending this authority to 200 miles (Government of Norway 1976a,b, 1978a, 1980, 1983a; Sen 1997). However, the administrative structures for fisheries management were developing, and the establishment of TAC-based

\footnotetext{
${ }^{16}$ In this chapter, to discard fish means to release or return fish to the sea (see glossary).
} 
management and national control over offshore fisheries through the new EEZ soon called for significant reform of fisheries law.

\subsubsection{The Emergence of an Enforcement Apparatus}

The Directorate of Fisheries reorganised and expanded in the early post-war years, and this trend continued during the 1960s and 1970s, as the fisheries gradually became regulated. The establishment of the $200 \mathrm{~nm}$ EEZ in 1977 was a watershed event in Norwegian fisheries management. Resource conservation was about to become a national responsibility, and a major political task, to a much greater extent than previously. At the same time, the fisheries administration reorganised and became much better suited to handle the challenge.

Until the 1970s, Norwegian fisheries laws mainly served as legal tools for promoting orderly fishing - solving and avoiding conflicts among fishermen on the fishing grounds. Consequently, an enforcement apparatus was established towards the end of the 19th century to ensure orderly fishing in the great seasonal fisheries - especially cod and herring. The supervisors enforced fisheries regulations ensuring order on the fishing grounds, but also served as advisors for the industry. This was the beginning of an advisory apparatus that developed throughout the 20th century, reflecting the state's role as promoter of industry development.

The advisory service became formalised through a separate act in $1972,{ }^{17}$ and was reformed into a coherent state administration under the Directorate of Fisheries in the early 1980s, keeping its dual tasks of supervising seasonal fisheries and providing industry advice (Government of Norway 1971c, 1978a, b, 1980, 1982a; Nordstrand 2000). The advisory service consisted of municipal fishery advisors headed by regional Chiefs of fisheries. In addition, the advisory service had fisheries boards on municipal and county levels.

The growing amount of regulations concerned with resource conservation and the emergent system of catch quotas required not only supervision of the large seasonal fisheries, but also permanent supervision and enforcement. Extending the control tasks of the advisory service was not regarded as the best answer to this challenge. Therefore, the enforcement of the state's resource conservation measures - the resource control - was left to the second major regional branch of the Directorate of Fisheries. This branch consisted of the quality control for fishery products that had developed since 1900 - the control service. The control service had expanded and encompassed an increasing number of agencies throughout the 20th century, as new products became subject to control. The entire apparatus reorganised and merged into a single administrative unit under the Directorate of

17 This act, which was called Lov om rettledningstjenesten i fiskerinceringen, was passed 11 June 1971 and entered into force in January 1972. 
Fisheries in 1977. The administrative apparatus originally built for the purpose of quality control covered the entire coastline and, by the late 1970s, it included approximately 130 regular employees in addition to a central staff at the Directorate of fisheries and several laboratories. The quality control had traditionally been performed as random checks at fish plants and fishing vessels along the coast. The same administrative apparatus and control procedures were used in the resource control as it gradually became a more important task. The control service thus was responsible for monitoring compliance with mesh size regulations, small fish regulations, closures of fisheries, and catch quotas (Government of Norway 1978b; Nordstrand 2000).

Despite these enforcement tasks, the resource control was still marginal compared to the quality control in the late 1970 s, and there was no effective enforcement of catch quotas. The fisheries administration lacked adequate regulations, experience, and educated personnel for the purpose of quota implementation. It took another decade before a reasonably effective quota control began to emerge. However, the central and regional fisheries administration that had been built since the turn of the century undoubtedly made it much easier for the Directorate of fisheries to eventually adapt to the new tasks.

The two regional branches of the fisheries administration developed into representations of the state's shifting roles. The advisory service continued to represent the state's traditional role as facilitator and promoter of industry development. It enforced 'old school' harvesting regulations aimed to handle potential conflicts among fishermen. The control service, with its increasing emphasis on resource control, was gradually shaped by the state's new role as resource manager and enforcer of regulated scarcity. This administrative structure and division of labour lasted for some 20 years until the two branches of the regional administration merged in 1998. The regional branch of the Directorate of Fisheries is generally referred to as the outer administration (ytre etat).

The outer administration of the Directorate of Fisheries was tasked with landbased control and supervision of the seasonal fisheries, which generally took place close to shore. With regard to sea-based controls, the Navy has played a role in Norwegian fisheries enforcement since 1907, when it assumed the task of keeping foreign fishing vessels out of Norway's territorial waters. From the late 1920s, it also started to provide services to the fishing fleet under offshore and distant water fisheries, and undertook the task of guarding fishing gear in international waters when gear conflicts between trawlers and fixed gear users became an issue. When a NEAFC agreement on mutual inspection of fishing vessels entered into force in 1970, the Navy became responsible for this task. The Navy thus had a significant history of fisheries law enforcement when quota implementation first required an apparatus for at sea inspections several years later. The establishment of the 200nm EEZ in 1977 implied important new tasks for sea-based enforcement of sovereignty and monitoring of the fisheries. These new tasks resulted in the establishment of the Coast Guard in 1977 (Christensen and Hallenstvedt 2005; Norway 
1975b). The Coast Guard became a key agency in sea-based fisheries law enforcement.

\subsection{7-2000: The Formation of Modern Fisheries Management}

\subsubsection{A New International Regime for Resource Conservation}

The preliminary outcome of the negotiations on the new Convention on the Law of the Sea allowed for $200 \mathrm{~nm}$ EEZs and made resource conservation a coastal state responsibility. In addition, it required states that shared stocks to co-operate for the purpose of conservation. The subsequent establishment of the $200 \mathrm{~nm}$ EEZs in 1977 marginalised NEAFC in fisheries management. However, by that time the Atlantic fisheries commissions had ensured the breakthrough of catch quotas as the dominant way to manage fisheries (see Chapter 2). Consequently, the new regime of bi-lateral and multi-lateral resource management that emerged from the mid 1970s built on this management strategy.

The establishment of the Norwegian $200 \mathrm{~nm}$ EEZ did not entail that the most important fish stocks were brought under exclusive Norwegian jurisdiction. Norwegian fishermen still harvested mainly from stocks that migrated between the EEZs of Norway and other states. Consequently, the establishment of the new EEZ took place along with a series of bi-lateral and multi-lateral negotiations for the management of shared stocks. Norway and Russia (USSR) had traditions of co-operation through the tripartite agreements for the 1971 herring fisheries and the 1974 cod fisheries (see Chapter 2), and of scientific collaboration, which had existed since the 1950s. Continuing their collaborative relations, Norway and Russia signed agreements on fisheries management in 1975 and 1976, establishing a joint fisheries commission responsible for setting and sharing TACs for the shared stocks in the Barents Sea: northeast arctic cod, haddock, and capelin. This collaboration also includes mutual exchange of quotas on exclusively-national stocks. Similarly, Norway and the EU made an agreement on the management of fish stocks in the North Sea, the Norwegian Sea and West of the British Isles in 1977. Similar to the agreement with Russia, TACs are set and distributed for several shared demersal and pelagic stocks through annual negotiations, in addition to mutual exchange of exclusively-national stocks. Norway entered an agreement with Iceland on the management of capelin migrating between the Icelandic EEZ and the Norwegian fishing zone around Jan Mayen in 1980. A tripartite agreement between Iceland, Greenland and Norway was signed for this stock in 1989. These new institutions for resource management were supplemented by a series of bilateral agreements on exchange or grants of exclusive fishing rights. 
The first attempts to present precise scientific estimates of stock size and development came during the 1970 s, although the figures were perceived as uncertain. ICES' Advisory Committee on Fisheries Management (ACFM) counselled the bi-lateral and multi-lateral commissions on the level at which to set their TACs, but the impact of the scientific stock assessments on the quotas in these early years has been questioned (Nordstrand 2000: 399-402). While historical fishing was the dominant factor in the distribution of quotas under the NEAFC regime, the stocks' zone belonging became a crucial criterion after the extension of the EEZs. The principle of zone belonging implies that the extent to which a transboundary stock resides within a given state's EEZ determines this state's rightful share of the TAC.

The institutional structures for resource management and distribution in the Northeast Atlantic are under more or less constant negotiation, subject to shifting international politics of fishing. Norway, Iceland, Russia, and the Faeroe Islands agreed on a TAC and national quota shares for Atlanto Scandian herring in 1996, and the EU entered this agreement in 1997. However, this agreement broke down in 2003, and the parties did not manage to agree on quotas and distribution for this stock until 2007. These states have also struggled to establish a management regime for the blue whiting fisheries, which evolved rapidly from the late 1990s. An agreement for management of this stock was reached for the first time in the autumn of 2005 (Government of Norway 1983a, 1995a, 2003a, 2005a; Nordstrand 2000). Implementation of the agreed TACs has mainly been a national matter: each state sets its own regulations concerning monitoring of fishing mortality and enforcement. This has resulted in differing implementation practices, which have caused tensions regarding the perceived willingness and ability of co-operating states to implement joint decisions. The cases presented in this volume describe significant variety in terms of capacity for implementation. At the end of this chapter, we will address the increasing effort over the past few years to build an international control regime.

The question of implementation was not a major issue when the new regime for resource conservation emerged on the international arena. Until the early 1970s, the main problem was to identify and agree on basic regulatory measures (see Chapter 2). The question of implementation emerged when solutions to this initial problem became institutionalised in the late 1970s. Regulation of fishing mortality through catch quotas entailed implementation difficulties, requiring an increasing amount of resources from the Norwegian fisheries administration in the years to come.

\subsubsection{Catch Quotas Gain Ground as a Resource Management Tool}

The early licensing schemes for specific fisheries, notably those based on the Trawler Act of 1951, were based on the perceived need regulate the relationships between gear types and between user groups. In the early 1970s, licensing also 
emerged as a measure for resource conservation. The collapse of the herring fisheries led the Ministry of Fisheries to use the authority granted it by the Participation Act of 1972 to introduce limited entry licensing for the pelagic purse seine fleet in 1973 - the year before NEAFC set its first TACs for herring. The Ministry introduced limited entry licensing in the seine fisheries for saithe in 1974 for similar reasons (Government of Norway 1981a, 1983a; NEAFC 1974). The role of limited entry licensing as a resource conservation measure faded as catch quotas gained ground in fisheries management.

The division of labour between catch quotas and capacity regulation in fisheries management resulted from disillusionment regarding the ability of structural policies to remove the need for restricting the domestic fleet's harvesting. The establishment of the $200 \mathrm{~nm}$ EEZ required a coherent fisheries policy, and the government outlined an ambitious "long-term plan for the Norwegian fishing industry", which identified the major political goals, problems and solutions for the industry, in 1977 (Government of Norway 1977a). This plan saw licensing policies and catch quotas as complementary management measures. It attempted to estimate the capacity reductions needed to adapt the fleet capacity to the fishery resource base, and stated that achieving balance between fishing capacity and the fishery resource was a major goal. The basic idea of this plan was to set scientificallybased catch quotas and adapt the fishing capacity to the catch possibilities represented by these. Successfully doing so would greatly reduce the need for detailed regulations of specific vessels or fleet sectors. ${ }^{18}$ This idea was also reflected in the Participation Act of 1972, which related its provision for specific licensing schemes to resource conservation, among other things. The Participation Act also provided for TACs until 1976, which underlines that in addition to ensure profitability in fishing, it was originally intended to be a tool in resource management (Garnment of Norway 1971a, 1972a, 1976d).

During the 1970s, limitations on fishing capacity through licensing policies played a significant role in resource management. The long-term plan of 1977 reflected optimism in terms of adapting fishing capacity to the fishery resource after the EEZ had been extended. However, the results were disappointing. The cod stock in the Barents sea remained weak for a number of years, as did the important herring and mackerel stocks. By the early 1980 s, the idea of using capacity restrictions as a tool in resource management had been abandoned. It was believed that only extremely strict licensing policies could reduce the need for regulation through catch quotas and technical fishing regulations, and that licensing schemes provided no alternative to catch restrictions. Fishery administrators began to recognise that catch restrictions likely were going to be necessary for many years to come. Consequently, the purpose of capacity restrictions became limited to ensuring profitable fishing and year round occupation for fishermen.

${ }^{18}$ As argued in Chapter 1, removing the need for catch quotas through capacity reduction schemes was quite optimistic, as resource fluctuations tend to make at least periodic catch restrictions necessary. 
From the early 1980s, following the loss of faith in the conservation abilities of structural policies, Norway's resource management was built on two pillars: total allowable catches and technical regulations, such as mesh size regulations, small fish regulations, and closed areas, aimed to minimise the content of juvenile fish in catches. The new Saltwater Fishing Act of 1983, based resource management on these two pillars, parting with structural policies as a resource conservation tool (Government of Norway 1981a: 16, 1983a). Implementation of resource conservation policies had thus been reduced to a question of implementing harvesting regulations. However, basing resource conservation entirely on harvesting regulations did not make implementation any easier. Abandoning the ambition of adapting fishing capacity to the TACs implied that vessel quotas were likely to be necessary in order to ensure economically-rational fishing. Adequate implementation of vessel quotas is one of the most difficult and complex tasks in fisheries management, because it requires systems for monitoring the vessels' catches and handling the problem of illegal incidental catch (see Chapter 1).

Perhaps the most striking feature of the long-term plan of 1977 was the lack of consideration for how the emergent catch quota regime could be implemented. The questions of how to monitor and control fishing mortality in order to realise target fishing mortalities had yet to be systematically addressed. Partly as a result of this, the question of enforcement was also not a major topic at this point of time. This is especially striking in a government white paper on the Control Service of the Directorate of Fisheries, published the same year (Government of Norway 1978b). While that paper pays much attention to quality control, and some attention to the enforcement of closed seasons and small-fish regulations, the question of how to enforce catch quotas is neglected entirely, save for the inclusion of the words "quota regulations" on a list of enforcement tasks.

The neglect of enforcement challenges was largely a result of the immaturity of fisheries law. A legal basis for quota control was still missing in the late 1970s: weighing regulations, sales note regulations, and logbook requirements had yet to be introduced. There really was not much to enforce in the way of catch quota regulations. We have seen that amendments to the Participation Act in 1976 allowed sales organisations to confiscate catch exceeding a vessel's quota. However, while these amendments placed new obligations on the fishermen's sales organisations, they did not entail new regulations for the fishermen. Thereby, the Norwegian fisheries policy and administration were still immature in terms of quota implementation in the late 1970s. The perceptions of the challenges associated with the new EEZs were largely shaped by previous problems and agendas. From a Foucauldian planning perspective, this may be seen as an example of institutionalised, inert discourse structures preventing new issues from receiving the attention they rationally could claim (Foucault, 1977, 1999).

The picture of inert institutional adaptation to the emergent TAC-based management regime is reinforced in the discourse on legal modernisation in the mid 1970s. In 1973, the government appointed a commission tasked with drafting a 
new act updating and replacing the Saltwater Fishing Act of 1955 and the Herring and Sprat Fisheries Act of 1937, thus finalising a 40 years process of legal simplification and modernisation (Government of Norway 1975c). However, when the report was published in 1975, the emergent new management regime - catch quotas and extended coastal state jurisdiction - had largely outdated the new proposal already. The proposed new act largely centred on the type of problems addressed in the previous acts - measures to ensure orderly fishing. Provisions for effective implementation of catch quotas, such as catch reports and logbooks, were absent.

Despite its failure to address the new management challenges, the 1975 report launched one new interesting idea: a ban on discarding dead and dying catch. The Saltwater Fishing Act of 1955 required that illegal catch be discarded immediately. The 1975 report suggested that this requirement for discards should be limited to undersized fish and catch taken during closed seasons, for "preventive and control purposes" (Government of Norway 1975c: 23). It suggested that the Ministry of Fisheries be authorised to ban discards of all other dead and dying illegal catch. The purpose of this was to avoid the waste of resources suited for human consumption. The scientific methods for the estimation of stock size and its development, for which reliable data on fishing mortality is essential, were still in their childhood years at this time. Partly as a result of this, the need to monitor fishing mortality was not on the agenda and, consequently, not considered in relation to the question of discards, although this has become an important consideration in more recent years.

The recommendations in the 1975 report went through extensive revision before the government proposed a new Saltwater Fishing Act to Stortinget (the Norwegian parliament) in 1982. By 1980, adapting the amount of fish caught to the level that can be sustained by the natural resource had become a dominant problem on the agenda of the Ministry of Fisheries. Consequently, by 1982, the legal text had changed from being a detailed outline of regulations, most of which aimed to ensure orderly fishing, to become an enabling act with implementation of TACs as its focal point (Government of Norway 1980: 25, 1982b). The new Saltwater Fishing Act of 1983 represented the first steps towards building a legal framework for implementation of TACs.

\subsubsection{A Legal Framework for the Implementation of TACs - The Saltwater Fishing Act of 1983}

The development of fisheries law, administration and market organisation before 1983 was important because it created several important conditions for the implementation of a TAC-based management regime. However, it was not developed with that task in mind. The Norwegian management system before 1983 lacked regulations and administrative routines for monitoring fishing mortality and aligning it with catch quotas. For example, the Saltwater Fishing Act of 1955 required 
that illegal catch be discarded. Consequently, discards of illegal catch was also required in the first quota-regulated fisheries in the 1970s. For example, the cod regulations of the late 1970 s explicitly prohibited fishermen from bringing illegal catch onto land (Government of Norway 1977b, 1978c). Similar to today's EU system of required discards of illegal catch, this implementation practice undermined the monitoring and, consequently, the control of fishing mortality.

As we have seen, there was great uneasiness about the discards policy in the Norwegian fisheries administration. The first attempt to align fishing mortality with catch quotas came, unsurprisingly, in the long-suffering herring fisheries. After many years of crisis, a minor fishery for Atlanto Scandian herring (so called "Norwegian spring spawning herring") was opened in 1981. There was clearly a perceived need to control fishing mortality for that stock, but the present Saltwater Fishing Act required discarding of illegal catch and did not provide for a ban on such a practice. Consequently, the first attempt to keep fishing mortality within the catch quota was made through administrative procedures rather than penal provisions. The 1981 herring regulations authorised the Directorate of Fisheries to issue permits and distribute the quota, and to respond to deliberate or incidental dumping of dead herring with a corresponding quota reduction or withdrawal of permit (Government of Norway 1981b). This was not a ban against discards, but rather administrative reactions aimed to deter fishermen from killing more herring than their quota prescribed. It can be considered an attempt to formulate modern regulations under an outdated act.

At that time, a legal framework much better suited to monitor fishing mortality and keep within quota limits was already in the making. The first significant tool developed specifically for the purpose of implementing target fishing mortality rates through catch quotas was the new Saltwater fishing act of 1983, which has since constituted the legal cornerstone of fisheries resource management. The new Saltwater Fishing Act gave broad authorisation to the Ministry of Fisheries to regulate the utilisation of marine living resources based on the two newlyestablished pillars of resource management: regulation of catch quantities through quotas and by-catch regulations, and measures to control catch composition in order to prevent fishers from filling quotas with undersized fish. The legal provisions for vessel quotas, as well as the sales organisations' tasks in implementing them were moved from the Participation Act to the new Saltwater Fishing Act, finalising a shift towards a clear division between structural policies and resource management.

Article 11 of the Saltwater Fishing Act represented an important change to the previous requirement for dumping illegal catch, stating that viable fish caught in violation of the act was to be released immediately. The Ministry of Fisheries was authorised to prohibit discarding of fish and fish waste products. However, one remaining insufficiency related to the authorisation to ban release of dead and dying fish before the catch is taken onboard. This is especially relevant in pelagic fisheries, where fish often dies in the seine before it is taken onboard. While the Ministry was authorised to ban all discards of dead and dying fish that had been 
taken on board, the authorisation to ban release of dead and dying fish before it is taken onboard only applied to catch taken illegally. This created an unintended loophole which, in principle, allowed for high grading of legal catch in pelagic fisheries. This insufficiency was rectified in 1988, when the provision in Article 11 to ban release of dead and dying fish was extended to all catch (Government of Norway 1988a, d).

The rationale for banning discards developed gradually. When this issue first came on the agenda in the mid 1970s, the argument related to waste of food resources (Government of Norway 1975c). The white paper preceding the new Saltwater fishing act of 1983, mentions resource waste, but also contains the first mentioning of the need to avoid "destroying the resources in the ocean" as a reason for preventing discards (Government of Norway 1982b: 23). By 1988, the rationale for preventing discards had found its modern formulation. The white paper that preceded the 1988 amendment to Article 11 of the Saltwater fishing act contains the first mention of the need for adequate data on fishing mortality as a reason for preventing discards of dead and dying fish (Government of Norway 1988a:24).

It was essential to the possibilities for implementing a ban on discards that the new Saltwater Fishing Act of 1983 continued and extended the legal provisions for non-penal forfeiture of illegal catch. This act provided for non-penal confiscation of all illegal catch, not only that which exceed a specific vessel quota. It contained three articles providing for confiscation of illegal catch, clarified through an amendment in 1988. Only one of these articles is a penal provision. Looking at the two non-penal provisions, Article 7 provides for confiscation by the fishermen's sales organisations of catch that exceeds the vessel's quota, while Article 11 provides for confiscation by the Directorate of fisheries of other illegal catch. In practice, the illegal catch is sold in a regular way; it is the outcome of the illegal catch that is confiscated. The confiscated outcome from sales of illegal catch belongs to the fishermen's sales organisations, regardless of whether confiscation is done on the basis of Article 7 or 11. Confiscation according to Articles 7 and 11 are administrative measures aimed at removing the incentive for illegal fishing, not punishment in a legal sense.

The provisions for non-penal confiscation imply that fishermen may land incidental illegal catch without fear of penalty, thus removing a potential incentive to conceal such catch through discards. In order to further remove incentives for discards, the new Saltwater Fishing Act also authorised the Ministry of fisheries to allow fishermen's sales organisations to compensate fishermen for bringing illegal catch to shore, provided that catching the fish was obviously unintended.

Articles 7 and 11 thus recognise that incidental catch is an inevitable part of fishing, and actively apply the principle of due care, which distinguishes between punishable and non-punishable violations. Recognising the inevitability of incidental catch and, consequently, applying a principle of due care is arguably important to the legitimacy of enforcement among fishermen. However, the non-penal nature of such confiscation also has another significant effect: it means that a 
fisherman will know that his illegal catch will have to be forfeited regardless of the authorities' ability to prove him liable to punishment. Consequently, the practice of non-penal forfeiture removes incentives for the fisherman to take advantage of the difficulty of proving criminal liability and thus pursue illegal catch deliberately.

Only in severe cases, where a punishable act can be proven, may a process of administrative confiscation result in a police report. Because confiscations according to Articles 7 and 11 are not penal measures, dissenting fishermen appeal to the Directorate of Fisheries rather than the court (Government of Norway 2006a: 37, 183). Confiscations on the basis of Articles 7 and 11 are done on a routine basis, irrespective of the fisherman's liability to punishment. However, if the illegal catch can be proven to have resulted from criminal negligence or intent, the fisherman may be taken to court and punished following conviction. In case of conviction, confiscation can be done in the form of penalty. Article 54 provides for penal confiscation of catch, fishing vessels, and fishing gear. While confiscation according to Articles 7 and 11 only entails that the illegal part of the catch is confiscated, Article 54 provides for confiscation of the entire catch when legally and illegally caught fish is mixed (Government of Norway 1983b, 1988a).

A major question in fisheries management - how to handle the inevitable problem of incidental catch - had thereby found an answer in the new Saltwater Fishing Act. Consequently, a major reason for requiring discards of illegal catch had been removed. By recognising that illegal catch often did not qualify for criminal liability and, consequently, making landing of incidental illegal catch a nonpunishable act, the Saltwater Fishing Act removed a potential incentive for fishermen to conceal illegal catch by discarding it. The administrative procedures for handling incidental catch were facilitated by the system of sales organisations that processed catch data, monitored vessel quotas, and administered the money-flow in the first hand trade of fish. The ability to create functional administrative procedures for handling landings of illegal catch became a central condition for the implementation of the ban against discards that emerged over the following years.

The Saltwater Fishing Act of 1983 was the first act to fully recognise the need to impose legal requirements on fishermen in order to implement TACs, and to back these up with suitable enforcement. Article 9 authorised the Ministry of Fisheries to issue regulations requiring fishers to report time, place, and quantity of catch, gear type, and catch value. The new Saltwater Fishing Act devoted an entire, new chapter to the enforcement of the new management regime. It divided the enforcement responsibilities between the Directorate of Fisheries, and the Coast Guard. The Directorate of Fisheries was granted inspection rights on fishing vessels and landing sites, and the Coast Guard was granted police authority and inspection rights at sea. The fishermen's sales organisations were included as a third enforcement agency through an amendment to this act in 1990. Table 3.1 describes what can be labelled the legal cornerstones for monitoring and controlling fishing mortality. The Saltwater Fishing Act is the basis for most of the important 
regulations. The Raw Fish Act, as has been described above, has centralised the first-hand trade of fish through the system of sales organisation and thereby provided important organisational structures for implementation.

Table 3.1. Legal cornerstones for monitoring and controlling fishing mortality

\begin{tabular}{|l|l|l|l|l|}
\hline $\begin{array}{l}\text { Legal } \\
\text { framework }\end{array}$ & $\begin{array}{l}\text { Regulated } \\
\text { activity }\end{array}$ & $\begin{array}{l}\text { Regulated } \\
\text { actors }\end{array}$ & Regulations & $\begin{array}{l}\text { Function in } \\
\text { resource } \\
\text { management }\end{array}$ \\
\hline $\begin{array}{l}\text { Saltwater } \\
\text { Fishing Act }\end{array}$ & Fish harvesting & $\begin{array}{l}\text { Fishers } \\
\text { Fish buyers }\end{array}$ & $\begin{array}{l}\text { Quotas } \\
\text { Catch reports } \\
\text { Ban on discarding } \\
\text { dead and dying } \\
\text { fish } \\
\text { Forfeiture of ille- } \\
\text { gal catch } \\
\text { Control } \\
\text { Technical regula- } \\
\text { tions }\end{array}$ & $\begin{array}{l}\text { Provide meas- } \\
\text { ures to restrict } \\
\text { and monitor } \\
\text { fishing mortality }\end{array}$ \\
& $\begin{array}{l}\text { Fish land- } \\
\text { ings/first hand } \\
\text { trade }\end{array}$ & $\begin{array}{l}\text { Fishers } \\
\text { Fish buyers }\end{array}$ & $\begin{array}{l}\text { Organisation of } \\
\text { first hand trade of } \\
\text { fish } \\
\text { Catch and landing } \\
\text { reports }\end{array}$ & $\begin{array}{l}\text { Provides organ- } \\
\text { izational basis } \\
\text { for implementa- } \\
\text { tion }\end{array}$ \\
& & & & \\
\hline
\end{tabular}

\subsubsection{Towards Alignment of Fishing Mortality with Catch Restrictions - The System Takes Effect}

The Saltwater Fishing Act of 1983 outlined the basic principles for quota implementation, but had few consequences in its own right, as these principles were only established in a series of enabling articles. The subsequent years were an intensive lesson for the fisheries administration on the problems of implementing target fishing mortality rates.

The early experiences with quota-managed fisheries in the 1980s made it clear that the management system was seriously lacking in implementation tools. Quotas generally, and vessel quotas specifically, generated several incentives for fishers to adapt in ways that undermined the purpose of the system. The insufficient implementation system resulted in significant unregistered fishing mortality, a problem which received increasing attention throughout the 1980s.

Concern about insufficient implementation resulted in the establishment of a working group to address the problem in 1986. This group consisted of three representatives from the Directorate of Fisheries and three from the Norwegian Fishermen's Association. It was tasked with mapping types of violations of fisheries law, and suggesting solutions to the problem. The composition of this 
group illustrates the extent to which the corporatist tradition in Norwegian fisheries management has stretched beyond the process of general policy formation and reached into the details of implementation. This extent of stakeholder participation has resulted from a long-term deliberate policy of making the industry a partner in management.

The report of this working group, presented in 1987, outlined the typical compliance problems associated with catch quota-based management. It pointed to the practice among fish buyers, especially in the pelagic sector, of requiring fishermen to give a certain part of their catch away for free when buying their fish. This practice entailed that fish buyers received a larger amount of fish than was officially declared or was deducted from the fishermen's quotas. Consequently, the practice of giving away catch led to unregistered landings of fish. Studies of fishermen's compliance conducted later, have confirmed that this was a widespread practice in the pelagic sector in the 1980s (Gezelius 2003, 2006). This practice was often embedded in the strong bargaining position of buyers. Giving a certain amount of the catch to the buyer for free did not necessarily imply a great disadvantage for the fisherman, as the unregistered landing would not be deducted from his quota and sometimes allowed for a higher price on the registered part of the catch. This practice has often been referred to as "delivering the big hundred" (storhundra) among Norwegian fishermen. The 1986 working group also pointed to the practice of fishing during a closed season and having the buyer enter it informally - "write it on the wall" - until the fishery opens. The catch was subsequently reported as if it had been taken during the open season. Another practice was to exceed area-specific quotas by falsifying information on where the catch was taken. The working group also pointed out the practice of falsifying information on the species landed. This latter practice was relevant when fishing a specific species was prohibited. For example, when the quota for one species had been exhausted fishermen could continue to fish for this species while "renaming" it into a different species upon delivery. This entailed that landings of, for example, herring could be registered as landings of, for example, mackerel.

The main problem with the implementation system of the 1980s was that the regulations did not provide for adequate control. It was illegal for a fisherman to exceed his quota, and it was illegal for a buyer to sell illegal catch. Violation of these rules could only be concealed through falsification of landing reports. The problem was that giving false information on landings was not a punishable act. As today, the catch report system was based on a system of sales notes, where the fishermen and the buyer fill in information on species and quantity, among other things, when the fish is landed. However, the sales note system was only embedded in the procedural rules of the fishermen's sales organisations, not state regulations (Government of Norway 1989a). Consequently, giving false or inadequate information in sales notes entailed no risk of legal prosecution. The only state response to such practices was that the Directorate of Fisheries would occasionally write a letter to fish buyers with a large number of incorrect or inadequate sales notes (Government of Norway 1988c). The enforcement of quota regulations was 
bound to remain ineffective as long as falsification of sales notes was not a punishable offence.

The inefficient implementation of catch quotas also related to discards. Although the Saltwater Fishing Act of 1983 provided for a ban, discards of dead and dying catch was still legal, and indeed required, in several fisheries in the mid 1980 s, because the legal authorisation to ban discards had yet to be used by the fisheries administration. The working group of 1986 pointed to the problem of "high grading" - i.e. discarding of the least valuable fish - that followed from the incentive to make as much money as possible out of vessel quotas. The general technical regulations of 1982 had prohibited fishing, as well as retention on board, of undersized fish. Similarly, the annual cod regulations had prohibited landings of illegal catch. Both these regulations implied a legal requirement to discard fish. As we have seen, there had been attempts to prevent excessive killing of AtlantoScandian herring through administrative action since 1981. The provision in the new Saltwater Fishing Act to ban discards was used for the first time in the Barents Sea capelin fisheries in 1985. The administrative measures applied in the herring fisheries were also supplemented with a ban on throwing herring back to sea in 1985, and a complete ban on discards of dead and dying herring (including releasing it from seines) in $1986^{19}$ (Government of Norway 1984a, b, c, 1985). However, the opposite principle - a ban on landing illegal catch - was still in force in the trawl fisheries for Northeast Arctic cod until 1987. At that time, an effort was made to make a ban on discards the rule rather than the exception in Norwegian fisheries. In the new general technical regulations of 1986, the prohibition against keeping undersized fish onboard was removed. The prohibition against landing illegal catch was also removed from the cod regulations that applied to the fishing season of 1987. In April 1987, separate regulations banned discards of cod and haddock in the trawl- and Danish seine fisheries in the Northeast Arctic (Government of Norway 1982c, 1986a,b, 1987a). A prohibition against discarding dead and dying fish, as well as of waste products, were established for the mackerel fisheries of 1988 (Government of Norway 1987b,c).

During this intermediary period, the meaning of "catch restriction" was ambiguous. In cases where discards were mandatory, catch restrictions referred (by implication) to fish landed. In cases where there was only a ban on throwing fish back to sea, they implicitly referred to catch taken onboard; in cases where all discards of dead and dying fish were prohibited, they referred to fish killed or made incapable of survival. The perceived need to clarify this is reflected in a government white paper from 1988 discussing how the concept of "catch" should be interpreted in relation to the ban on discards. This whitepaper argued that the separation of fish from the remaining stock marked its transition into catch (Government

19 This is another example of how the development of the regulations has been ahead of the development of an enabling act in relation to discards. It is notable that the Saltwater Fishing Act at that time provided for a ban on throwing any catch back to sea, but in relation to the release of dead and dying catch, e.g. from seines, the provision only applied to illegal catch. However, the herring regulations of 1986 actually banned the release of any dead or dying catch. 
of Norway 1988a: 24). In practice, the Norwegian system requiring release of viable illegal catch and banning release of dead and dying catch restricts the killing of fish following its separation from the stock.

An amendment to the general technical regulations made in August1988 was a major step in the direction of adequately monitoring fishing mortality. It established a general ban on discards of dead and dying fish in the Norwegian EEZ, regardless of area, gear type and fleet sector. Initially, this ban applied to cod, haddock, saithe, redfish, mackerel, and herring. Capelin, whiting, blue whiting, Greenland halibut, angler, shrimp, and snowcrab have since been added to this list (Government of Norway 1988b, 1989b, 2004c). In principle, these regulations aligned catch quotas with fishing mortality and, thereby, conceptualised TACs legally as a resource management tool.

Despite regulations banning discards of dead and dying fish, the administrative procedures for implementation had yet to adequately ensure that fishing mortality and catch quotas were aligned in practice. One problem related to the absence of administrative tools suited to deduct forfeited catch from the TACs such that fisheries could be closed before the TAC was exceeded. This is a problem which remains to a certain extent even today, a point to which I will return. The second problem was how to enforce the system.

The 1986 working group's mapping of illegal practices led to the formation of a second working group in 1988, tasked with recommending improvements to the enforcement system. It consisted of representatives of the Directorate of Fisheries, the Ministry of Fisheries and the fishing industry represented by the two biggest fishermen's sales organisations. As has been described above, the sales organisations had had implementation responsibilities relating to the monitoring of vessel quotas and the confiscation of certain types of illegal catch for number of years already, and the role of the sales organisations in the implementation of conservation policies was going to expand over the next few years. Therefore, the participation of the sales organisations in the 1988 working group was more than routine hearing of industry views. It formed part of a growing state/industry partnership in the implementation of TACs. The Norwegian Sales Organisation for Pelagic Fish, which was one of the sales organisations represented in the 1988 working group, suggested to the group that falsification of sales notes ought to be illegal and that all recipients of fish landings should be required by law to keep correct landing records (Government of Norway 1988c). This recommendation was followed by Norwegian authorities, and became a cornerstone in the quota implementation system.

This process resulted in significant upgrading of the legal framework for quota implementation, which shaped the basic features of today's system for monitoring catches. In the autumn of 1989, Stortinget (the parliament) amended the Saltwater Fishing Act and the Raw Fish Act, extending and clarifying the authority of the Ministry of fisheries to require catch reports. The Ministry now became authorised to require detailed catch reports from fish buyers, as well as vessels processing their own catch (Government of Norway 1989a, c). The ensuing regulations 
concerning vessels processing their catch onboard (Government of Norway 1989 d, e) were subsequently extended to the transfer of catch between vessels at sea (Government of Norway 1996b, c). Today's regulations allow catch to be transferred over the side to vessels from specific states under detailed report requirements (Government of Norway 2005b).

The 1989 amendment to the Saltwater Fishing Act authorised the Ministry of Fisheries to define the role of the fishermen's sales organisations in resource control, and pertinent instructions followed in 1991 (Government of Norway 1991). These instructions required the sales organisations to establish control procedures for the implementation of the Saltwater Fishing Act. The sales organisations were also required to report detected illegal incidents to the Directorate of Fisheries. The fishing industry's partnership with the state in fisheries law enforcement had now become embedded in law. This amendment also extended the authorisation of the control service of the Directorate of Fisheries so as to allow for investigations of the accounts of fishing companies, control of temporary storage facilities, as well as requirement of data from vessels and companies shipping catch abroad (Government of Norway 1988a, d, 1993a). The control authorities of the Directorate of fisheries were extended further in an amendment to the Saltwater Fishing Act in 2001. The authorisation to access information needed for control purposes was extended and clarified so at to cover all relevant agencies, documents and facilities relating to trade, transport or storage of fish for commercial purposes. The authority of the Directorate of Fisheries has thus been gradually extended from controlling fishing activities to also controlling the subsequent activities (Government of Norway 2001a, b, 2007e: 113).

The 1989 amendments to the Saltwater Fishing Act enabled the fisheries administration to fix major holes in the implementation system. The following years saw the establishment of core regulations in resource management. Following the additions to the Saltwater Fishing Act and the Raw Fish Act, the Ministry of Fisheries started using its authority to establish regulations for quota control. The sales note regulation of 1990 was a landmark event in terms of solving the problem of black landings. This regulation required the buyer to weigh the catch and to fill in sales notes according to the instructions of the sales organisations. The buyer and the fisherman were required to sign the sales note and they were jointly responsible for giving correct information. ${ }^{20}$ These regulations entailed that falsification of sales notes became subject to legal prosecution. For control purposes, the fisherman had to keep copies of the sales notes onboard the fishing vessel. The sales note regulations also required the buyer to keep records of their fish buys, which provides for control e.g. through comparing buys with sells. These basic principles of the catch monitoring system have remained the same since 1990. All catch has to be weighed at delivery, and signed sales notes submitted to the sales organisation with correct information on the quantity of each species landed and when and

${ }^{20}$ The fisherman has sole responsibility for the correctness of the sales note when landing fish abroad. 
where it was taken. The sales organisations register all information in a data base that is accessible to the Directorate of Fisheries. However, these general principles have gradually developed into more detailed requirements. In the pelagic sector, where some buyers have been known for requiring the big hundred, manipulating scales or in other ways embezzling catch, scales regulations were introduced from the mid 1990s requiring that the scales have sealed total counters that buyers cannot reset and displays of landed quantity clearly visible to the fisherman (Government of Norway 1995b, 1996a). Fishermen have reported that these regulations greatly reduced the problem of embezzlement of catch (Gezelius 2003, 2006). These requirements apply to all Norwegian fisheries today: the buyer is required to have officially-approved scales at the wharf, with displays easily accessible to the fisherman. Today's regulations specify rules for tagging and traceability of landed catch, enabling control of buyer's warehouses and accounts (Government of Norway 2003b).

The late 1980s and early 1990s can rightfully be labelled the construction phase of today's fisheries management system. Not only were the basic implementation tools for TAC-based management established, but this was also the period when the majority of Norwegian fishermen became subject to genuine quota-based restrictions on fishing. Previously, catch quotas effectively restricted only offshore vessels: the poor conditions of the Northeast arctic cod and important pelagic stocks entailed that the cod trawlers and the purse seiner fleets became the first strictly-regulated fleets. These fleets were subject to vessel quotas in the early 1980s. However, the vast majority of fishermen, who fished inshore, were not affected by quota regulations. The cod quotas set through negotiation with Russia only applied to trawlers until 1981 . The quota agreement with Russia continued to allow vessels only using passive gear (gillnets and hook and lines) to continue fishing after the national quota share had been taken. Both Russian and Norwegian authorities began to worry about the extent of Norwegian fishing within this arrangement. Consequently, restrictions on the inshore fleet in the form of closed seasons, gear restrictions and maximum quotas per vessel were introduced from 1983 in order to delimit the overstepping of the Norwegian quota (Government of Norway 1983a). However, the ability to overfish the national quota with passive gear remained until 1988 (Government of Norway 1992). Throughout the 1980s, it became clear that the condition of the Northeast Arctic cod stock was not improving, and in 1989 the stock was estimated to be at an all-time low. Up to this point, catch quotas had mainly affected the offshore fleet, but from then on, the ability for Norwegian fishers to overfish the quota with passive gear was removed (Sagdahl 1992: 50), and a vessel quota regime was introduced in this fleet as well. Thereby, the majority of Norwegian fishermen had become included in the new resource management regime. 


\subsubsection{Organisation of the Resource Control}

As a result of the emergence of regulations for implementing TACs, the quality control of the Directorate of Fisheries was instructed to increase the priority of resource control in 1988 (Government of Norway 1989a: 20). The improved legal basis for implementation and the inclusion of the inshore fleet in the vessel quota regime around 1990 entailed that resource control became a dominant task for the control service of the Directorate of Fisheries.

Since the amendments to the Saltwater Fishing Act in 1990, the resource control has been split between three agencies: the Directorate of Fisheries, the fishermen's sales organisations, and the Coast Guard. These organisations co-operate on a regular basis in order to coordinate enforcement practices and clarify interpretations of legal rules.

The Directorate of Fisheries began its control activities under the modernised regime for quota implementation with dockside inspections. These are random spot checks where inspectors compare the data in sales notes and logbooks with landed quantities. From the mid 1990s, the Directorate of Fisheries also began to carry out random checks of fish buyers' accounts in order to monitor compliance with weighing and sales note regulations. It also inspects warehouses in order to compare changes in stored quantities with the buyers' records of purchases and sales. The gradual development towards inspection of accounts and storage facilities has required higher competence among inspectors than the traditional dockside inspections did. Consequently, the Directorate of Fisheries has found it necessary to improve the education of its inspection personnel in recent years (Government of Norway 2006a: 195-7).

From 1999, fishing vessels over $24 \mathrm{~m}$ have been required to install satellite tracking devices which transfer data on vessel movements to the Directorate of Fisheries. Report procedures, including reports of quantities and composition of catch, for Norwegian vessels fishing in international waters were introduced at the same time (Government of Norway 1999a, b). In 1998, an amendment to the Saltwater Fishing Act provided for the use of onboard observers for resource control, a major purpose of which was to improve the enforcement of the ban on discards (Government of Norway 1998a, b). The Directorate of Fisheries has a few onboard observers in the surveillance service for the Barents Sea fisheries. ${ }^{21}$ However, only three positions are devoted to this task, and observer coverage has yet to play a significant role in regular resource control (Government of Norway 2005c: 187).

The Directorate of Fisheries has regional offices responsible for resource control. The two branches of the outer administration - the control service and the advisory service - merged in 1998. The responsibility for quality control

${ }^{21}$ This surveillance service was established in 1984 for the purpose of observing the densities of small fish on fishing grounds in the Barents Sea and advising the Directorate of Fisheries on closures of these fishing grounds (Hallenstvedt 1993). 
was removed from the fisheries administration following the establishment of the Norwegian food safety authority in 2004, leaving resource control as the main enforcement task of the fisheries administration. Today, the Directorate of Fisheries has 7 regional offices headed by Regional Directors responsible for resource control and advisory services. Each regional office has several offices on the municipal level. The fish inspectors provide their regional offices with written reports from each inspection. In cases where the Regional Directors finds a basis for prosecution, the offence is reported to the police. From then on, the role of the Directorate of fisheries is to provide evidence and act as counselling expert in the event of a court case. The regional offices are also responsible for administrative confiscation of illegal catch according to Article 11 in the Saltwater Fishing Act. In severe cases, the process of administrative confiscation may result in a police report. Figure 3.1 illustrates the basic elements in catch quota implementation. The boxes signify the main actors. Dotted arrows indicate actions carried out, while unbroken arrows indicate flows of material and information.

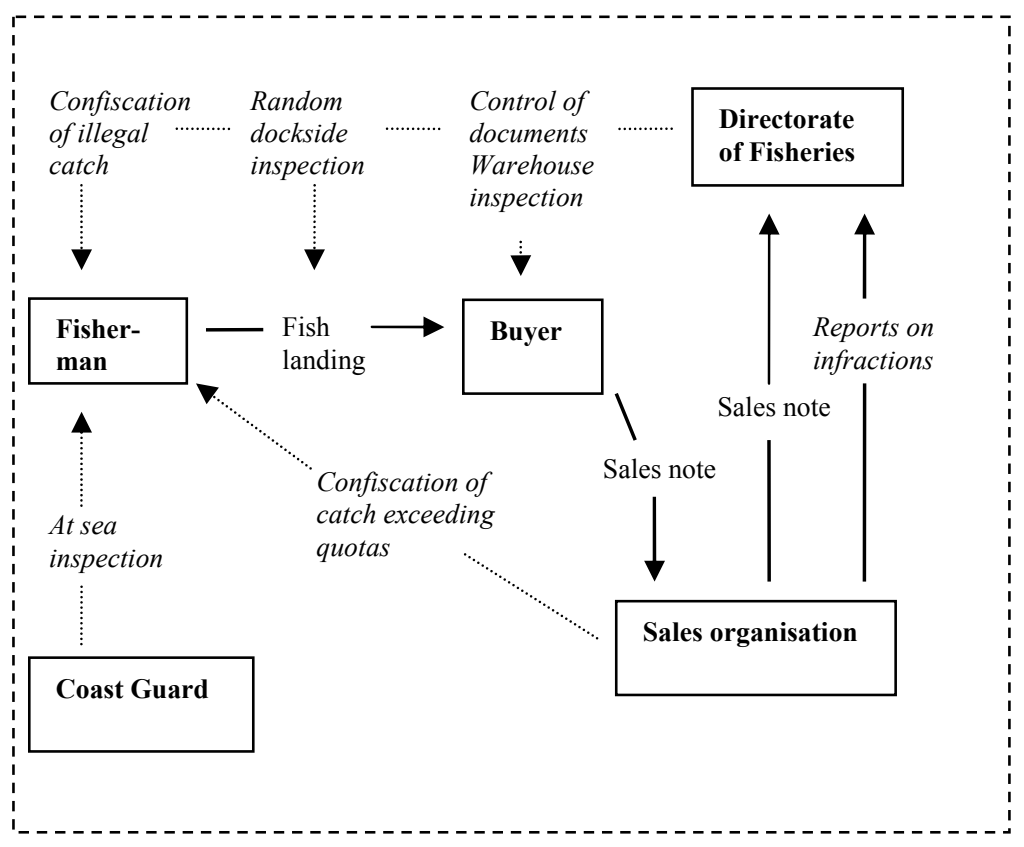

Fig. 3.1. The quota implementation system

The fishermen's sales organisations monitor quota regulations and confiscate catch that exceeds vessel quotas. They also routinely report detected violations of fisheries law (Government of Norway 2004a). For example, the Norwegian sales organisation for pelagic fish incorporates all new regulations in their electronic fleet and catch monitoring systems, keeping track of the relationships between quotas, participation rights and landings. Much of the sales organisations' control 
is based on documents, but they also have a few inspectors who monitor fish landings at landing sites, controlling procedures for writing sales notes and procedures for weighing. The sales organisations also assist the inspectors of the Directorate of Fisheries by providing data on the registered activities of fish buyers. ${ }^{22}$ The Coast Guard is responsible for surveillance and enforcement at sea, and is granted police authority in relation to those tasks meaning that it is authorised to board and arrest vessels. It carries out onboard inspections, controlling catch composition, fishing gear and comparing logbook and sales note information, on a routine basis. It also monitors the ban on discards. It reports major infractions to the police, and functions as a witness in court cases.

Table 3.2 summarises the main problems in catch quota implementation and the current status of Norway's efforts to solve them. Reports from fishermen clearly indicate that the problem of black landings was reduced greatly when the sales note/weighing regulations were put in place. Compliance research has concluded that black landings of fish are dwindling in Norwegian fisheries. Although it used to be widespread, falsification of sales notes, which accompany black landings, is no longer generally accepted in the industry (Gezelius 2003, 2006).

Table 3.2. Problems and solutions in quota implementation

\begin{tabular}{|c|c|c|c|c|}
\hline $\begin{array}{l}\text { Problem in } \\
\text { quota im- } \\
\text { plementation }\end{array}$ & $\begin{array}{l}\text { Regulatory re- } \\
\text { sponse }\end{array}$ & $\begin{array}{l}\text { Enforcement } \\
\text { practice }\end{array}$ & $\begin{array}{l}\text { Implementation } \\
\text { effectiveness }\end{array}$ & $\begin{array}{l}\text { Informal com- } \\
\text { pliance factors }\end{array}$ \\
\hline $\begin{array}{l}\text { Preventing } \\
\text { black sales } \\
\text { of fish }\end{array}$ & $\begin{array}{l}\text { Sales } \\
\text { note/weighing } \\
\text { regulations } \\
\text { Logbook regu- } \\
\text { lations }\end{array}$ & $\begin{array}{l}\text { Dockside } \\
\text { inspections } \\
\text { Warehouse } \\
\text { inspections } \\
\text { Document } \\
\text { controls }\end{array}$ & $\begin{array}{l}\text { Mature system. } \\
\text { Problem greatly } \\
\text { reduced. }\end{array}$ & $\begin{array}{l}\text { Shifting } \\
\text { attitudes in } \\
\text { favour of } \\
\text { compliance } \\
\text { among fishers }\end{array}$ \\
\hline $\begin{array}{l}\text { Preventing } \\
\text { discards of } \\
\text { dead and dy- } \\
\text { ing fish }\end{array}$ & $\begin{array}{l}\text { Ban on discards } \\
\text { of dead and dy- } \\
\text { ing fish } \\
\text { Compensation } \\
\text { for landing ille- } \\
\text { gal incidental } \\
\text { catch in demer- } \\
\text { sal fisheries. }\end{array}$ & $\begin{array}{l}\text { At sea inspec- } \\
\text { tions. } \\
\text { No penalty for } \\
\text { landing illegal } \\
\text { incidental catch. } \\
\text { Closed areas and } \\
\text { caution areas to } \\
\text { reduce catch of } \\
\text { juveniles. }\end{array}$ & $\begin{array}{l}\text { Mature regula- } \\
\text { tions. } \\
\text { Immature en- } \\
\text { forcement due to } \\
\text { inadequate defi- } \\
\text { nitions of "dying } \\
\text { fish" and prob- } \\
\text { lems of detection } \\
\text { and legal evi- } \\
\text { dence - few } \\
\text { court cases. }\end{array}$ & $\begin{array}{l}\text { Ban on dis- } \\
\text { cards has } \\
\text { unanimous } \\
\text { support among } \\
\text { fishers. } \\
\text { Reciprocity- } \\
\text { based ex- } \\
\text { change of sur- } \\
\text { plus catch in } \\
\text { pelagic sector. }\end{array}$ \\
\hline
\end{tabular}

Logbook regulations were applied to certain fisheries beginning in the mid 1980s, but gained a significant role in enforcement in the early 1990s after the sales note regulations had been introduced. Vessels over $13 \mathrm{~m}$ are required to keep logbooks with data on the quantity of each species caught and the location and time of the catch. The logbook must be kept up-to-date, and always completed

${ }^{22}$ Pers. comm. Norwegian sales organisation for pelagic fish. 
before the vessel calls at harbour. Fishermen are required to keep the logbooks for the previous two years on board the vessel (Government of Norway 1986c, $1993 \mathrm{~b}, \mathrm{c})$. A major purpose of today's logbook requirements is to reduce the incentive to falsify sales notes by increasing the risk of detection. The logbook requirements entail that a fisherman who plans to falsify his sales note must begin by falsifying his logbook. A falsified or incomplete logbook implies a risk of being detected by unannounced dockside inspections. Intentional or careless violation of logbook regulations is subject to legal prosecution, and the principle of due care is enforced strictly, bordering on a practice of strict criminal liability (Dahl 2002).

While the implementation of fish landing reports has reached a fairly mature stage, implementing the ban on discards of dead and dying fish still raises some difficulties. The main strength of today's system is that it quite effectively reduces costs of compliance. Unless he was obviously careless when catching the fish, the fisherman risks nothing in terms of legal sanctions when bringing in the catch. The illegal part of the catch is forfeited, but a compensation scheme was introduced in 1999 (Government of Norway 1999c) entailing that, in demersal fisheries, the fisherman normally receives $20 \%$ of the catch value as a compensation for bringing it to shore. Forfeited catch will not be deducted from the quotas of the fisherman. Defining "carelessness" in legal terms is difficult, but the Coast Guard uses a practice of "caution areas" in order to reduce this problem. The designation of caution areas provides information to the fishing fleet about areas with large quantities of undersized fish or high risks of illegal by-catch and function as advice that fishermen would be wise not to fish within those areas. The caution areas are not closed to fishing, but vessels who fish there risk prosecution when they end up with illegal catch (Pers. comm. Coast Guard 2005). Since 1984, the Directorate of Fisheries has also had an apparatus to ensure timely closing of areas with high densities of juveniles in the Barents Sea (Hallenstvedt 1993). Both of these measures aim to decrease the risk of illegal catches. They also reduce the risk of fishermen filling their quota with unprofitably small fish. Consequently, they are assumed to reduce discards.

Regulation wise, the system for preventing fish discards is arguably fairly mature, because it reduces incentives to discard illegal incidental catch without creating great incentives to pursue such catch deliberately. However, enforcement of the ban on discards is still a difficult matter. While the system quite effectively reduces the fisherman's costs of complying with the ban on discards, it is arguably less effective in terms of imposing costs on fishermen who do not comply. This ineffectiveness of enforcement relates primarily to three factors. First is shaky knowledge and thus a vague legal definition of when fish should be considered "dying". This is mostly a problem in the pelagic fisheries, where release of fish usually takes place before the catch is taken onboard. The annual regulations in pelagic fisheries have thus stated, in general terms, that release of dying fish is illegal and supplemented this with a final limit related to the fishing operation. Until 2004, this limit took the form of a statement saying that catch cannot be released 
after pumping of the catch from the seine into the vessel has begun under any circumstances. Due to the inadequate definition of "dying fish", only this final limit was enforced, and the fishermen perceived releasing fish prior to this point to be legal. In the mackerel fisheries in 2004, the mention of the pumping operation as a final limit to the release of fish was removed from the regulations. Instead, the Coast Guard arranged meetings with fishermen informing them of how the concept of "dying fish" would be interpreted in enforcement: the Coast Guard would start reacting to instances where catch was released after the fish had been concentrated to the point where it began jumping in the seine. This implied a stricter enforcement practice because fish normally starts jumping in the seine before the pumping operation begins. The second factor concerns insufficient clarification of the principle of due care in relation to unintended dumping as a result of torn seines and cod ends. Consequently, the requirement for display of due care has yet to be enforced in such cases. Third is the fact that it is often difficult to find out, and virtually impossible to prove, who discarded the catch, because this requires direct observation of the act of discarding. This problem is also especially significant in pelagic fisheries, as fish is usually discarded before it is taken out of the water. Fatty fish, such as herring, floats to the surface when dead, which increases the risk of detection. However, catches are often made when the fish concentrates right before darkness, and discarding is difficult to detect at night. Mackerel, for example, sinks immediately, which makes detection almost impossible unless there are observers onboard. Arguably, this problem can only be properly solved once gear is developed that allows fishers to estimate size and quality of the catch while the fish is still viable, thus removing the incentive to delay release until the fish is dead or dying (Gezelius 2006). These difficulties in proving criminal liability resulted in an absence of court cases related to discards in pelagic fisheries for a number of years. As a result of the efforts of enforcement authorities to fix these inadequacies, the Coast Guard has over the past couple of years reported a few vessels for discarding pelagic fish (Gezelius 2006; Government of Norway 2004b). ${ }^{23}$

The state's approach to resource control in fisheries aims to be nonprovocative. No enforcement personnel carry arms, and incidents of violence are extremely rare. Coast Guard personnel, although operating in military uniforms, are instructed to behave in a polite and non-provocative manner. During

${ }^{23}$ In December 2007, the Government published the proposal for a new act - Act on the Management of Wild Marine Living Resources (Havressursloven) - to replace the Saltwater Fishing Act of 1983. The proposal suggests that the rules regarding discards are made somewhat stricter. The Ministry of Fisheries and Coastal Affairs proposes that fishermen are required by law to bring all catch to shore, regardless of viability. The purpose of this is to simplify enforcement by making it less dependent on judgement of the catch's viability. However, the need to make exceptions to this general rule is recognised, as is the legitimate need of purse seiners to release viable catch from the seine early in the seining operation (Government of Norway 2007e). Consequently, the extent to which the new and stricter rules against discarding solve the present enforcement problems in the pelagic sector is unclear. 
fieldwork in the offshore fishing fleet in 2003 and 2004 (see Gezelius 2006), the author witnessed a gentle and communicative enforcement practice among Coast Guard personnel, and cooperative responses among fishermen. In offshore and distant water fisheries, the Coast Guard also provides certain services, such as information on the regulations of other states, medical services, and scuba divers in cases of emergency. Consequently, the Coast Guard does not only act as enforcer, but also as a support for the fleet, which likely contributes to cooperative attitudes among fishermen and, thereby, eases enforcement. ${ }^{24}$

Violations of fishing regulations are usually violations of the Saltwater Fishing Act, which provides for three types of legal sanctions: fines, confiscation of catch, vessel, and gear, and imprisonment. Previously, imprisonment could only be used in cases of repeated violations or aggravating circumstances and was limited to a maximum of 6 months. Media attention to fisheries crime resulted in a sharpening of the provisions for imprisonment in the Saltwater Fishing Act in 2001. There is now a regular provision for 6 months in prison, and aggravating circumstances can result in a maximum of two years in prison. A typical penalty in fisheries court cases consists of a fine for the fisherman and confiscation of valuables belonging to the fishing company. In practice, confiscation often functions as a fine, as the Saltwater Fishing Act provides for confiscation of the monetary value rather than the physical items.

Minor infractions, and especially those resulting from negligence, are often not reported to the police and, consequently, are settled outside the court system. The most common way for the Directorate of Fisheries or the Coast Guard to deal with such cases is to issue a warning. The Participation Act has also provided for withdrawal of licenses when the conditions for the license are no longer fulfilled. However, when fisheries law enforcement entered the agenda in the late 1980s, the fisheries administration was reluctant to use such sanctions due to the questions of legal protection they raise (Government of Norway 1989a: 24). This policy has changed in recent years, and administrative sanctions have started playing a certain role in fisheries law enforcement. The new Participation Act of 1999 increased the possibilities for administrative sanctions, stating that the required license to own a fishing vessel can be permanently or temporary withdrawn in cases where the vessel has violated fisheries law. Today, the Directorate of Fisheries occasionally uses temporary withdrawal of fishing licences as an alternative to prosecution through the court system (Government of Norway 1999d, 2003c; pers.comm. Directorate of fisheries and the Coast Guard).

\footnotetext{
${ }^{24}$ I owe to Jesper Raakjær the point that combining enforcement with other services may also have undesirable effects, as vessels fishing illegally may be reluctant to call for help.
} 


\subsubsection{The Logistics of Information}

The Norwegian management model is based on the ideal of aligning catch restrictions with fishing mortality. Achieving this is demanding in terms of administrative efficiency. It is not sufficient to ensure that all fish killed during fishing is landed and reported. The logistics of catch information must also be efficient enough to ensure that governing agencies are kept up to date on the relationship between landed quantities and Norway's total quota. Time lags in information transfer represent a danger of overfishing the TAC.

In today's system, the fish buyer transmits the sales note to a fishermen's sales organisation. The sales organisations subsequently transmit sales note data electronically to the Directorate of Fisheries once or twice per week. The Directorate of Fisheries then updates its catch statistics database on basis of this information. Quota information is transmitted from the Directorate of Fisheries to the sales organisations daily (Government of Norway 2006a).

A significant problem in quota implementation has related to a provision in the Raw Fish Act that allows fishermen to process their own catch. This provision entails that not all catch is sold at the time of landing, which has resulted in significant time lags since sales notes are not transmitted until the catch is sold. This problem has been on the agenda since 1996 and resulted in new regulations on catch report procedures in 2003. These regulations required the transfer of landing notes to the sales organisations in cases where the fish was not sold at the time of landing. The system of landing notes is currently being implemented electronically by the sales organisations (Government of Norway 1951a, 2003b, 2006a: 31-34).

A similar problem relates to forfeited catch. Catch that is confiscated administratively is not subtracted from the individual quotas of the fishermen, in order to remove incentives to discard. However, aligning catch quotas with fishing mortality requires subtracting forfeited catch from the total Norwegian quota. At present, Norway has no system in place to ensure that aggregate data on fish landings, including forfeited catch, can be continuously compared with Norway's total quotas. This is not a major problem in the pelagic sector, because individual quotas in the offshore fisheries amount to slightly less than Norway's total quota. This prevents illegal, forfeited catch from resulting in overfishing of the total quota. The fact that all catches are sold through a centralised auction system also ensures efficient transfer of landing data. Norway's total quotas for herring and mackerel have not been greatly overfished in recent years (Government of Norway 2006a: 190-91). However, the system has yet to function adequately in demersal fisheries, which has less efficient procedures for transfer of data on fish landings. The lack of computerised tools allowing for real-time comparison of data in the central catch statistics database with total quotas makes it difficult to keep an up-to-date overview (Government of Norway 2006a; pers. comm. Directorate of fisheries). 
The potential problem of overfishing is enhanced by the quota system applied in the inshore cod fisheries. In recent years, inshore fishermen have been granted one quota that covers cod, saithe, and haddock. This increases flexibility and reduces by-catch problems, but makes overfishing of favoured species difficult to prevent. This system of one single vessel-quota for these three species was removed in the regulations for 2007 (Government of Norway 2007d).

\subsection{0- : Globalising the Implementation Effort}

Most major fish stocks harvested by Norwegian vessels are either straddling or highly migratory, which means that they are shared with other countries. Consequently, a functional national implementation system is insufficient to ensure sustainable resource management. Realisation of conservation targets requires that all major harvesting nations implement catch restrictions with a certain degree of effectiveness. There are many potential legal and administrative obstacles to achieving this, but one obstacle is especially significant because of its potential to reduce the efforts of other states: the incentive to free-load on the conservation effort of others. In theory, asymmetrical implementation efforts could lead to a prisoner's dilemma-like logic in resource management, where free riders subvert the general willingness by states and companies to carry the costs of conservation.

These dangers of asymmetrical implementation have been conspicuous in the Norwegian public discourse on illegal and unregistered fishing of Northeast Arctic cod, which is managed jointly by Norway and Russia, in recent years. In Norway, it is generally believed that Norwegian implementation of catch regulations for this stock works reasonably well and that illegal fishing for this stock by Norwegian vessels is not a major problem today. However, there has been great concern about illegal and unregistered fishing by foreign, especially Russian, vessels in recent years. ICES (2007) estimated that the unreported catches amounted to approximately $25 \%$ of the official catches in 2006 . Transhipment of catches from the Barents Sea to cargo ships, which transport the catches to European ports for sale, is considered as the most common way of avoiding quota control in these fisheries. Illegal fishing of Northeast Arctic cod has caused much frustration in the Norwegian fishing industry, and has resulted in industry organisations arguing that Norway should withdraw from its management agreement with Russia (Fiskaren 2006b; NRK 2006). The feeling of being exploited by free riders and losing out in a prisoner's dilemma game has also been expressed in the Norwegian fisheries press, as illustrated in this leading article in Norway's biggest fishing industry newspaper.

The Norwegian fishing industry is being robbed by obeying the law... Russian fishers have done as EU fishers have for years, fished on an official quota and landed 
unofficially. The only growing stock, at a time when the ocean offers excellent conditions for production, is the saithe. But, notably, we manage the saithe stock ourselves. (Leading article Fiskaren June 7 2006a, my translation).

States in the Northeast Atlantic require foreign fishing vessels to report their catch when entering or leaving their EEZs so as to keep track of catch taken within their EEZ. Norway has required catch reports from foreign vessels since 1977. In 1994, it also introduced a requirement for foreign vessels to report to specific control points after having finished fishing, allowing for inspection. Requirements for satellite tracking, established through agreements among coastal states in the North-East Atlantic, have increased the enforceability of these regulations (Government of Norway 2007a; ICES 2007). However, such measures do not solve problems of illegal, unregulated and unreported (IUU) fishing in international waters or in the waters of neighbouring states. The concern about foreign IUU fishing has triggered a Norwegian diplomatic effort to establish an effective international control regime. This has included the establishment of several bilateral agreements, as well as an active role in NEAFC.

As described in Chapter 2, the establishment of national control over offshore fisheries through the introduction of $200 \mathrm{~nm}$ EEZs in 1977 deprived the NorthEast Atlantic Fisheries Commission (NEAFC) of its main resource management functions. However, the UN agreement on the management of straddling fish stocks and highly migratory fish stocks, established in 1995, renewed the significance of the international fisheries commissions and improved the legal foundation for international resource management, including control and enforcement (UN 1995). The significance of NEAFC has been reinforced by the increasing concern over foreign IUU fishing in recent years. In 2005, NEAFC established a so-called "black list" of fishing vessels banned from fishing in the NEAFC area. In 2007 this ban was also extended to the EEZs of NEAFC's member states. In addition to being banned from fishing, black listed vessels are denied access to ports and services in NEAFC states. The Northwest Atlantic Fisheries Organization (NAFO) has established a similar measure (Government of Norway 1993d, 2007a, b). Norway established legal provisions for the exclusion of black listed vessels from port services, landing and transhipment of catch at Norwegian ports in 2006. In addition to these multi-lateral arrangements, Norway has since 1998 unilaterally black listed foreign vessels perceived to undermine Norwegian conservation efforts through unwanted fishing in waters outside Norwegian jurisdiction. Black listed vessels are permanently denied fishing rights in Norwegian waters (Government of Norway 1966, 1998c, 2006b, 2007e).

The establishment of the NEAFC black list was followed by the agreement on the NEAFC Scheme of Control and Enforcement in 2006, which entered into force the following year (Government of Norway 2007a; NEAFC 2007). This agreement was a significant step forward in terms of international quota control. It establishes measures to monitor fishing activities and transhipment of catch in international waters. Importantly, the agreement also establishes a regime for port 
state control to prevent landings of illegal catch. This regime requires all vessels intending to land frozen catch in a foreign NEAFC port to notify the port state in advance and provide it with catch data. The port state is subsequently committed to contact the ship's flag state in order to verify that the catch has been legally taken. If the legality of the catch cannot be verified, the port state is committed to deny landing. It is also committed to carry out inspections of at least $15 \%$ of the landings or transhipments in its ports. These inspections shall include comparison of the data in the ship's prior notification of landing with the actual quantities landed or transhipped. Information on quotas and landings are transmitted to NEAFC's online database for purposes of transparency (Government of Norway 2007a, c; NEAFC 2007).

Norway actively promoted the establishment of the port state control regime, and currently works within the FAO system to build a similar regime on a global scale (Government of Norway 2007a). The Norwegian participation in efforts to establish multi-lateral implementation systems has been accompanied by a number of bi-lateral control agreements. Norway has control agreements with most major fishing nations in the North-East Atlantic, and has begun to update these to allow for the exchange of information on fish landings from third-state vessels (Government of Norway 2007a).

\subsection{Legitimation Strategies}

At the time when the EEZs were established and the state undertook the task of resource management, the Norwegian Fishermen's Association organised the entire fish harvesting sector and had become the government's dominant industry partner. The Norwegian Fishermen's Association had been a prime advocate for the development of important parts of the legal and administrative system, such as the establishment of the fishermen's sales organisations in the 1930s, the establishment of a Ministry of Fisheries in 1946, and the development of the advisory service of the Directorate of Fisheries. The Norwegian Fishermen's Association had been chosen by the government as the sole counterpart to the state in the annual negotiations for subsidies to the fishing industry through the Basic Agreement of 1964 (Hallenstvedt \& Dynna 1976: 272-283). The close connection between the industry organisations and the state administration were reinforced by the extensive exchange of personnel across state/industry boundaries. Several Fisheries Ministers have had prominent positions in the Norwegian Fishermen's Association, including chairman and secretary general. For example, Klaus Sunnanå, the Director of Fisheries from 1948 to 1973 and one of the most influential civil servants in the history of Norwegian fisheries management, had a past as secretary in the Norwegian Fishermen's Association (Government of Norway 1975a; information from the Norwegian Fishermen's Association). 
As the focal point of governance moved from industry development to resource management, and intra-industrial conflicts of interest thereby became politicallydominant, the Norwegian Fishermen's Association became a crucial actor in the legitimation of fisheries policies based on its strong position as counsellor for the Ministry of Fisheries. The relationship between the Ministry of Fisheries and the Norwegian Fishermen's Association thus developed into a mutually-beneficial political exchange. The Ministry of Fisheries secured an enduringly strong position for the Norwegian Fishermen's Association by granting it genuine and partly exclusive influence on management policies. In return, the Norwegian Fishermen's Association undertook the politically-hazardous task of transforming conflicting interests into uniform industry advice. Consequently, it provided management policies with the legitimacy that goes with industry support, and relieved the Ministry's political leadership of the political stress that goes with arbitration (Gezelius 2002a).

The Norwegian Fishermen's Association is granted influence at all levels in fisheries policy formation, beginning with the decisions on TACs. The main industry organisations are consulted in forming the Norwegian position in the international quota negotiations. The Norwegian Fishermen's Association and two other industry organisations (one representing the offshore crews and one representing the processing industry) are also active members in the Norwegian delegation in international quota negotiations (Government of Norway 2005a). The position of the Norwegian industry organisations as adequate delegation members is quite unique in this context, as the industry organisations of counterpart states generally only have status as observers.

Once the TACs have been set, the process of setting the annual regulations for the fleet begins. The Directorate of Fisheries prepares recommendations on regulations to be presented to the Regulatory Meeting. The Regulatory meeting replaced the Regulatory Council in 2006. The Regulatory Council was a body of industry organisations established for the purpose of counselling the Minister on regulations set under the Saltwater Fishing Act. It was established following the Saltwater Fishing Act of 1983, replacing the previous Regulatory Committee. It was headed by the Director of Fisheries and consisted of thirteen members. One seat was occupied by the Director of Fisheries and one seat was occupied by the counties. The remaining eleven seats were occupied by representatives from the main industry organisations. The Norwegian Fishermen's Association was the dominant actor with five members in the council (Government of Norway 1997, $2005 \mathrm{~b}$ ). The advice of the council was presented directly to the Ministry of Fisheries, which makes the final decisions. The Minister of Fisheries almost always followed the advice of the Regulatory Council, which relieved him/her of the political stress associated with autonomous decisions. This practice provided an incentive for council members to reach a negotiated consensus, as they had less control over the outcome of state arbitration. The Regulatory Council most often managed to provide advice through negotiated consensus, but in cases where this was not possible, the different positions were communicated to the Ministry of Fisheries with 
a record of the votes, allowing the Minister to follow the majority when he/she needed legitimation of controversial decisions. However, a legal requirement for a minimum $40 \%$ representation of women in advisory boards led to the temporary abolishment of the Regulatory Council in 2006. The Regulatory Council was replaced with the Regulatory Meeting. While the Regulatory Council was a closed hearing forum limited to a defined set of active participants and an additional set of observers, the Regulatory Meeting is an open hearing forum. The former members of the Regulatory Council are specially invited to the meetings, but the meetings are now open to any organisation which registers within the deadline. All participants have the right to speech, and there is no voting. The Directorate of Fisheries organises the meeting. The minutes from the meeting are sent to the Ministry of Fisheries and Coastal Affairs. The advice from the Directorate of Fisheries is transferred separately. Some industry organisations have voiced a wish to return to the previous Regulatory Council, but the future form of these hearings is currently somewhat uncertain. ${ }^{25}$ The wish of some industry organisations to return to the previous arrangement of the Regulatory Council is unsurprising because the new hearing forum arguably shifts the balance of power from the industry to the Directorate of Fisheries and the Ministry of Fisheries. The strictly framed negotiations and uniform advice of the Regulatory Council gave its representatives a level of influence which is difficult to achieve in the Regulatory Meeting. Potentially, this shifting balance of power also makes decision-making more politically-costly for the Minister of Fisheries.

The provision of unitary industry advice has been an important feature of this corporatist system. The organisational structure of the Norwegian Fishermen's Association is reminiscent of a political party, and controversies are settled through voting procedures. This includes the highly-controversial question of setting principles for quota distribution among fleet sectors. The Regulatory Council traditionally based its quota allocation advice on guidelines set by the Norwegian Fishermen's Association. The Minister of Fisheries could thus distribute quotas on the basis of uniform industry advice, from which the Minister rarely departed. Provided that the Norwegian fishermen's Association continues to handle the allocation issue, its advice is likely to continue to have decisive influence on the allocation decisions of the Ministry of Fisheries and Coastal Affairs. Regulations are continuously updated, and there is ongoing dialogue, at formal and informal levels, between the fisheries administration and the Norwegian Fishermen's Association on these matters. This corporatist system is based on a model for fisheries management aimed to minimise the political costs for state agencies. Uniformity of industry advice and a government practice of following this advice are the core elements of this low-cost approach. This legitimation strategy implies that the state has exchanged some of its political autonomy for political peace.

Consequently, tensions between the state and the industry have been reduced at the cost of generating great intra-industrial conflicts that have often threatened the

\footnotetext{
${ }^{25}$ Source: Pers. comm. Directorate of Fisheries 2 January 2008.
} 
unitary structure of the Norwegian Fishermen's Association. The genuine and often decisive influence that the main industry organisations have received in return for their willingness to carry political costs potentially increases internal tensions due to the importance of their advice. On the other hand, this influence has also provided the various interest groups with incentives for continuing to support their organisations.

The corporatist model of fisheries management does not only apply to bottomup advisory processes. It also applies to implementation. The enforcement responsibilities of the fishermen's sales organisations are embedded in law, which gives the sales organisations certain semi-governmental features. The Norwegian Fishermen's Association also fulfils implementation tasks at a more informal level. The Fishermen's association is often the fisherman's main source of information regarding fisheries regulations. The tight connections between this union and the fisheries administration entails that local union leaders are kept up to date on regulatory changes. This function has been institutionalised in the offshore sector where the Directorate of Fisheries transmits new regulations to the vessel owner's association which faxes them to the fishing companies. ${ }^{26} \mathrm{New}$ regulations are also published on the homepages of the Norwegian sales organisation for pelagic fish.

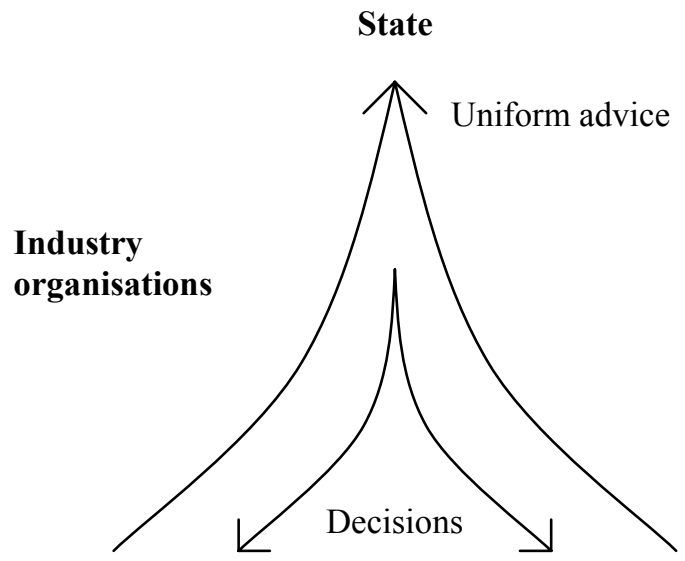

Heterogeneous and geographically-dispersed industry

Fig. 3.2. Industry organisations as a communication funnel

Consequently, the industry organisations function as a two-way communication funnel between the state and the industry, as is illustrated in Fig. 3.2. This

${ }^{26}$ Pers. comm. Directorate of Fisheries and the Norwegian Fishing Vessel Owners Association. 
communication funnel aggregates views and interests into unitary advice upwards and spreads information on decisions downwards, which contributes to the blurring of perceived distinctions between state and industry. This corporatist model has thus counteracted the development of polarised and antagonistic state/industry identifications (Gezelius 2003). These identifications have relevance for implementation. I have argued elsewhere that building shared state/society identifications is important in order to generate normatively-based compliance, documenting the existence of an informal social norm among Norwegian fishers requiring them to obey fisheries law, as well as a relative absence of antagonistic state/industry identifications in the industry (Gezelius 2002b, 2003, 2006). The corporatist structures of fisheries management and the extensive exchange of personnel between the industry and the state thus also have possible implementation relevance through their ability to increase fishermen's identification with the state and thereby facilitate informal norms of compliance.

If we consider the role of the fishing industry from the introduction of TACs in the early 1970s and until a reasonably coherent implementation regime had been constructed some 25 years later, it is evident that the industry was not included as an afterthought to the construction of the TAC-implementation regime, but rather constituted an essential partner in this construction process from the beginning. The sales organisations were granted implementation tasks in the early years of TACs in the mid 1970s, and the Norwegian Fishermen's Association and the sales organisations were significant actors in the making of the implementation regime during the period of its basic construction: the 1980s and the 1990s. Arguably, this has promoted a joint state/industry identity in relation to the Norwegian TACimplementation system, as well as a sense of shared responsibility. The Norwegian discourse regarding the effectiveness of Norwegian implementation compared to other states also suggests a fair degree of shared pride in terms of what has been achieved. A somewhat extreme manifestation of this was the proclamation by a Norwegian Minister of Fisheries in the mid 1990s that Norway was the "world champion of fisheries management" (Hersoug 2005: 4). A similar view was recently expressed by Norway's current Minister of Fisheries and Coastal Affairs, Helga Pedersen: "We have the best fisheries management in the entire world". ${ }^{27}$

The long-term policy of the fisheries administration to promote shared state/industry identifications must be considered to have been relatively successful. This relative success can hardly be ascribed to the fisheries administration alone, as it has been facilitated by a political culture that is the most trusting and supportive in Europe in terms of citizens' attitudes towards their national government and politicians (Aardal 1999; Aardal et al. 1999; Miller \& Listhaug 1998). This political culture has, in turn, been promoted by a national idea largely constructed around the main legal institutions - the Constitution, the Constitution Day and the Storting (Norwegian parliament) - which became the most prominent na-

${ }^{27}$ Helga Pedersen to NRK Dagsrevyen (national Television news), March 13, 2008 (my translation). 
tional symbols alongside the flag during the 19th century (Seip 1997; Sørensen $1998 \mathrm{a}, \mathrm{b})$. This means that the project of counteracting conflicting state/industry identifications in the fishing industry could build upon a political culture that was receptive to the idea of state/society partnerships. The content of the national idea thus has facilitated the social norms of law-abidingness that can be observed in the industry today.

Table 3.3. Historical development of the management system

\begin{tabular}{|c|c|c|c|c|c|c|}
\hline & $1900-50$ & $1950-60$ & $1960-70$ & $1970-80$ & $1980-90$ & 1990- \\
\hline $\begin{array}{l}\text { Develop- } \\
\text { ment of } \\
\text { resource } \\
\text { manage- } \\
\text { ment }\end{array}$ & $\begin{array}{l}\text { Resource } \\
\text { manage- } \\
\text { ment of } \\
\text { secondary } \\
\text { importance }\end{array}$ & $\begin{array}{l}\text { Aware- } \\
\text { ness of } \\
\text { overfish- } \\
\text { ing. Fo- } \\
\text { cus on } \\
\text { technical } \\
\text { measures. }\end{array}$ & $\begin{array}{l}\text { Discussions } \\
\text { on } \\
\text { reformed } \\
\text { manage- } \\
\text { ment } \\
\text { regimes: } \\
\text { TACs ver- } \\
\text { sus effort } \\
\text { regulations. }\end{array}$ & $\begin{array}{l}\text { Interna- } \\
\text { tional nego- } \\
\text { tiations } \\
\text { over access, } \\
\text { manage- } \\
\text { ment rights } \\
\text { and quota } \\
\text { shares }\end{array}$ & $\begin{array}{l}\text { Implemen- } \\
\text { tation be- } \\
\text { comes a } \\
\text { pressing is- } \\
\text { sue. Devel- } \\
\text { opment of a } \\
\text { basic } \\
\text { framework } \\
\text { for quota } \\
\text { implemen- } \\
\text { tation. }\end{array}$ & $\begin{array}{l}\text { Incre- } \\
\text { mental } \\
\text { improve- } \\
\text { ment of } \\
\text { the im- } \\
\text { plementa- } \\
\text { tion sys- } \\
\text { tem }\end{array}$ \\
\hline $\begin{array}{l}\text { Resource } \\
\text { manage- } \\
\text { ment form }\end{array}$ & & $\begin{array}{l}\text { Technical } \\
\text { measures }\end{array}$ & $\begin{array}{l}\text { Technical } \\
\text { measures }\end{array}$ & $\begin{array}{l}\text { Catch quo- } \\
\text { tas, techni- } \\
\text { cal regula- } \\
\text { tions, } \\
\text { structural } \\
\text { policies }\end{array}$ & $\begin{array}{l}\text { Catch quo- } \\
\text { tas and } \\
\text { technical } \\
\text { measures }\end{array}$ & $\begin{array}{l}\text { Catch } \\
\text { quotas } \\
\text { and tech- } \\
\text { nical } \\
\text { measures }\end{array}$ \\
\hline $\begin{array}{l}\text { Main } \\
\text { govern- } \\
\text { ment task }\end{array}$ & $\begin{array}{l}\text { Industry } \\
\text { develop- } \\
\text { ment }\end{array}$ & $\begin{array}{l}\text { Industry } \\
\text { develop- } \\
\text { ment }\end{array}$ & $\begin{array}{l}\text { Industry } \\
\text { develop- } \\
\text { ment }\end{array}$ & $\begin{array}{l}\text { Industry } \\
\text { develop- } \\
\text { ment/ } \\
\text { resource } \\
\text { manage- } \\
\text { ment }\end{array}$ & $\begin{array}{l}\text { Resource } \\
\text { manage- } \\
\text { ment }\end{array}$ & $\begin{array}{l}\text { Resource } \\
\text { manage- } \\
\text { ment }\end{array}$ \\
\hline $\begin{array}{l}\text { Condi- } \\
\text { tions for } \\
\text { quota im- } \\
\text { plementa- } \\
\text { tion }\end{array}$ & $\begin{array}{l}\text { Establish- } \\
\text { ment of } \\
\text { sales or- } \\
\text { ganizations, } \\
\text { fishermen's } \\
\text { union. } \\
\text { Strong } \\
\text { state/indust } \\
\text { ry connec- } \\
\text { tions. } \\
\text { Building of } \\
\text { central and } \\
\text { regional } \\
\text { fisheries } \\
\text { administra- } \\
\text { tion. }\end{array}$ & $\begin{array}{l}\text { Expan- } \\
\text { sion of } \\
\text { fisheries } \\
\text { admini- } \\
\text { stration. }\end{array}$ & $\begin{array}{l}\text { Fleet sec- } \\
\text { tors merge } \\
\text { in a single } \\
\text { dominant } \\
\text { union. } \\
\text { Partnership } \\
\text { with the } \\
\text { state for- } \\
\text { malized in } \\
\text { the Basic } \\
\text { Agreement. }\end{array}$ & $\begin{array}{l}\text { National } \\
\text { control } \\
\text { over conti- } \\
\text { nental } \\
\text { shelf. Re- } \\
\text { organisa- } \\
\text { tion of re- } \\
\text { gional con- } \\
\text { trol } \\
\text { services. } \\
\text { Establish- } \\
\text { ment of the } \\
\text { coast } \\
\text { guard. }\end{array}$ & $\begin{array}{l}\text { Modernised } \\
\text { legal } \\
\text { framework. } \\
\text { Formalisa- } \\
\text { tion of in- } \\
\text { dustry role } \\
\text { as advisor } \\
\text { and imple- } \\
\text { menter in } \\
\text { resource } \\
\text { manage- } \\
\text { ment. }\end{array}$ & $\begin{array}{l}\text { Devel- } \\
\text { opment of } \\
\text { enforce- } \\
\text { ment ap- } \\
\text { paratus. } \\
\text { Sales or- } \\
\text { ganisa- } \\
\text { tions ful- } \\
\text { fil key } \\
\text { tasks. }\end{array}$ \\
\hline
\end{tabular}




\subsection{Concluding Analysis: Causes of Continuity in Norwegian Fisheries Management}

\subsubsection{Continuity}

The development of the Norwegian management system has gone through several distinct phases, each roughly coinciding with one decade, as is illustrated in Table 3.3. The 1960 s were a period of deliberation on the principal choices of fisheries management within the framework of the Atlantic fisheries commissions. These discussions ended in a breakthrough for TACs as the preferable management tool. The 1970s were a period of bi-lateral and multi-lateral discussions on the principles for setting and distributing TACs. This period saw the first TACs and national allocations in the Northeast Atlantic. The 1980s were the period of learning how to implement the system at the national level. Aligning fishing mortality with catch quotas is the fundamental problem in TAC implementation and, consequently, the question of effective monitoring and restriction of fishing mortality gained a prominent place on the agenda during this decade. The focus on these issues resulted in the establishment of the basic legal and administrative frameworks for catch quota implementation. The 1990s were the period of fixing holes in the implementation system, and the first decade of the new millennium has been a period of globalising the implementation effort.

Norwegian fisheries management implementation has been subject to constant change, but changes have typically been evolutionary rather than revolutionary. Continuity has thus been a hallmark of Norwegian fisheries management. This continuity relates to the basic management approach of conserving fishery resources through catch regulations, but also to the institutional structures for implementation. The past few years have been marked by confidence crises and radical reorientations in the management of many North Atlantic fisheries, but Norway represents a case of comparable stability in this context. The TAC-based management model is by and large undisputed in the public debate. As of yet, alternative management regimes are scarcely discussed outside academic forums. The Norwegian management system has evolved through gradual change of implementation schemes rather than radical change of the basic management principles. $^{28}$ There have been no disruptive crises of confidence in the system's ability to

\footnotetext{
28 The recently-proposed Act on the Management of Wild Marine Living Resources, aimed to replace the Saltwater Fishing Act, confirms this picture. This proposed act continues the existent implementation system while fixing perceived holes in the present implementation system. For example, it proposes that the Sales Organisations are given extended authority to fulfil their control tasks, that the Ministry of Fisheries and Coastal Affairs is authorised to require registration by all actors receiving fish landings (not only buyers), and to require traceability of catches (Government of Norway 2007e).
} 
manage fishery resources, and implementation failures have usually been addressed as matters of fixing the holes in a system that is perceived as basicallysound. The dynamic of this continuity has been outlined in this chapter, but it is worthwhile addressing some factors explaining this apparently unique continuity.

\subsubsection{The State of the Fish Stocks as a Cause of Continuity}

The continued trust in the system is partly contingent on the absence of enduring resource crises in Norwegian fisheries in the post-EEZ period. After the recovery of the herring fisheries which collapsed in the late 1960s, the pelagic fisheries have not faced severe depressions. Periodic fluctuations, especially in the capelin fisheries, have not undermined the basic trust in the system. The cod fisheries went through a crisis in 1989-90, but the stock apparently recovered rapidly, and Norway emerged as an exceptional case of successful management in the 1990s when crises in the cod fisheries were widespread in the North Atlantic. Norwegian fisheries management has thus been considered relatively successful. The extent to which the viability of the fisheries is due to competent management, resilient fish stocks, pure luck or a combination of these is debatable, but there is no doubt that the continuity of the fisheries management system has been facilitated politically by the absence of enduring fishery resource crises.

\subsubsection{Path Dependence and Functional Implementation as Causes of Continuity}

\section{The Lucky Strike of History}

Apart from the uncontrollable biological and oceanographic factors, successful TAC-based management depends on two main factors: TACs set on the basis of sound scientific advice and implementation ensuring that the fishing mortality does not exceed the TACs. In the Norwegian public debate, most attention is paid to the question of the soundness of scientific advice and how it relates to the TACs. The view that aligning fishing mortality with TACs represents unmanageable implementation problems has never gained foothold in the Norwegian discourse. The general view is also that Norway has come a long way compared to most other states in achieving this. Although the faith in Norway's superior implementation may contain a national bias, it arguably also relates to the fact that certain historical conditions gave Norway a head start in the implementation of the new TAC-based regime. When TAC-based resource management emerged in the mid 1970s, a basic institutional infrastructure for implementation had already been established. The outer administration of the Directorate of Fisheries, which had 
been developed for the purposes of industry development and quality control, was also well suited to resource control. Consequently, when the perceived need for resource control became pressing in the late 1980s, this apparatus simply took on these new tasks. Moreover, the centralised organisation of the first-hand fish market, established in the late 1930s, provided for easy registration of catch quantities and, consequently, for monitoring quotas. It also offered a handy solution to one of the most difficult questions in TAC-based management - how to administer landings of illegal incidental catch. Because the system of fishermen's sales organisations offered a solution to this problem, it was relatively easy for the state to implement a ban on discards of dead and dying fish. The market organisation thereby facilitated the monitoring of fishing mortality.

The strong connections between the fishermen's sales organisations and the state made it possible to delegate enforcement and other implementation tasks to these organisations, counteracting polarised state/industry identifications in matters of resource management. Similarly, the unitary structure of the fishermen's union and its tradition for close interaction with the state provided for uniform industry advice that was influential to the extent that the fishing industry emerged as the state's equal partner in resource management, facilitating informal compliance norms.

In sum, the structures of the market, industry and administration that had been constructed throughout the 20th century offered solutions to some of the biggest problems of TAC-based management. This had nothing to do with historical foresight, but resulted from more than 70 years of incremental development mainly motivated by problems other than resource management. When resource management emerged as a major challenge, the existent institutions and traditions of politically-low-cost management proved useful, as is illustrated in Fig. 3.3.

Looking at the system for implementation of conservation policies, Norwegian fisheries management is, in Lindblom's (1959) terms, a case of a management system muddling through, incrementally adapting to new challenges through trial and error. It is also, in David's (1985) terms, a case of path dependent development, meaning that solutions for the future are largely built upon the structures of the past. Such incremental and path dependent development is not special to the implementation of resource conservation policies. It is arguably a general feature of Norwegian fisheries management. For example, Hersoug (2005) has used the same theoretical labels to describe the development of the Norwegian system for allocating fishing rights. 


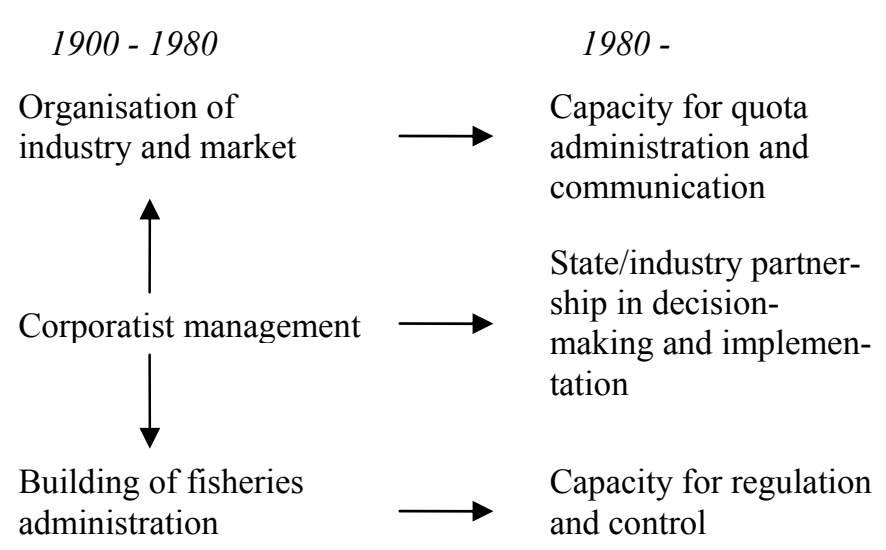

Fig. 3.3. Historical factors in management continuity

The rationality of path dependency relates to the often high costs associated with building new structures. Even when new structures may function more effectively than old ones, the costs of establishing these often outweigh the benefits. Throughout the development of the Norwegian implementation system, using the existent organisational structures often emerged as the least costly option in the short term. Consequently, the organisation of the administration and industry that took place from the early 1900s had a decisive impact on the shape of the system for catch quota implementation. However, the apparent viability of this system can hardly be accounted for by path dependence alone. It is essential to the continuity of the system that the existent organisation of the market, industry and administration, by chance, proved fairly suitable for the task. They allowed for regulations that otherwise could have been difficult to implement. A significant amount of resources have thus been invested in the development of a regulatory framework enabling these organisations to implement management policies. Consequently, this path dependence also applies to fisheries law. Today's fisheries legislation consists of a complex set of regulations constructed on the basis of several coordinated laws that are manifest in organisations and routines. This set of institutions has evolved as a long-term project of trial and error. It would take strong reasons to change the basic structures of this system today. The experiences of the system's functionality vis-à-vis the industry and, apparently, the fish stocks do not represent strong reasons for change at present. 


\section{Viability of Conservation Goals}

We have seen that the Norwegian government has assumed responsibility for industry development and resource conservation. The conservation task has also been followed by significant challenges related to the distribution of fishing rights (Christensen and Hallenstvedt 2005; Hersoug 2005; Sagdahl 1992). At the political level, especially in relation to TAC levels, concerns about the industry's shortterm survival and distributional problems have represented a potential challenge to resource conservation as the dominant political value (Gezelius 2002a; Jentoft 1991:11-16; Sagdahl 1992). However, previous research on state/industry interaction in relation to implementation (Christensen et al. 2007; Gezelius 2003), as well as the research underlying this study, has not yielded any data to indicate that conservation goals are changed or challenged to any great extent at the implementation stage. ${ }^{29}$ Chapter 6 on implementation politics in Denmark and the EU presents a contrasting case to Norway in this respect. It is reasonable to hypothesise that the apparent robustness of conservation goals in the implementation process is one significant condition for continued faith in the functionality of the Norwegian resource management system and thus for its continuity. In the following, I will argue that this relative robustness results from distinct structures of power in Norwegian fisheries management.

Following the emergence of TACs as a resource management form in the early 1970 s, the implementation system to a great extent developed through interaction between four main agencies: the Directorate of Fisheries, the Ministry of Fisheries, the Norwegian Fishermen's Association and the sales organisations. The development of the Norwegian implementation system has thus emerged as an incremental bottom-up process to a great extent, driven by the state administration and the industry organisations. New regulations have typically emerged in response to experienced insufficiencies in present implementation. The process of constructing the implementation system has thus had a practical rather than an ideological orientation. However, the bottom-up nature of this construction process is embedded in the combination of two consciously-chosen traditions in Norwegian governance. First is the corporatist tradition, which emphasises negotiation and cooperation between industry organisations and the state. Second is the tradition for delegating decision-making power to the state administration through enabling acts. Norwegian acts are often quite general and relatively short, authorising the state administration to decide upon regulatory specifics. The implementation system has thus largely developed through regulations, while general legal amendments have provided the necessary extensions of the administration's regulatory authority. This combination of corporatist governance and enabling legisla-

${ }^{29}$ This finding relates to the construction of the implementation system. As of yet, there are no studies of how formal implementation structures shape administrative decisions at the micro level in the fisheries management system. For example, the extent to which informal social norms and values influence Norwegian fisheries inspectors' decisions to report or ignore observed infractions has not yet been studied. 
tion has entailed that important decision-making processes related to conservation policies and implementation have taken place at low levels of the Norwegian hierarchy of authority.

TAC implementation could in principle be disturbed by the agendas of shifting fisheries ministers under such a system, potentially undermining conservation goals. However, significant factors prevent a change of goals at the implementation stage. The enabling legislation, which leaves responsibility for setting and implementing TACs to the Ministry of Fisheries, is crucial to understanding the robustness of the conservation agenda in implementation. Norway's TACs are mostly consensus decisions made through negotiations between the Norwegian Ministry of Fisheries and the main Norwegian industry organisations on the one hand, and the delegations of counterpart states on the other. The consensus nature of conservation decisions and the central role of the Ministry of Fisheries and industry organisations in the decision-making process entail that the main actors in implementation are also responsible for the conservation policy, which strongly discourages reopening the political discussion at the implementation stage. ${ }^{30}$ It can also be argued that the long-term, routine nature of TAC-based management has enhanced the enabling legislation's capacity to keep decision-making at low levels in the hierarchy. The TAC regime has existed and evolved over a period of many years, despite shifts in the administration's political leadership. The system for implementing this regime has similarly evolved incrementally in the direction of increased effectiveness, despite several changes of government. It appears that the routine, long-term, complex, and technical nature of TAC-based management has entailed that operating this management system has to a great extent been defined as an administrative responsibility. Consequently, the development of the implementation system has largely emerged as an incremental bottom-up process, relatively uninfluenced by the shifting agendas of political leadership. ${ }^{31}$ Studies have concluded that the Norwegian administration generally displays a large degree of loyalty towards original political aims in the implementation process (Christensen et al. 2007: 120-133), and the data in this study largely confirm that picture. The data suggest that the implementation agenda has largely been shaped by the administration's perceived need for improved implementation tools.

\footnotetext{
${ }^{30}$ There are exceptions to the loyal implementation of bilateral/multilateral agreements. The annual agreements between Norway and the EU regarding herring in the North Sea and Skagerak include a separate herring quota to be caught exclusively in Skagerak. Norway has wanted to remove this spatial separation of quotas for several years, but it has remained part of the agreement due to the EU's wish. Norway has subverted this arrangement at the implementation level by not enforcing it. Non-compliance with the North Sea/Skagerak division line is widespread in Norwegian herring fisheries (Gezelius 2007: 418).

${ }^{31}$ Although independence of shifting political agendas appears to be the general picture, there have been some observable deviations. One of the most conspicuous deviations came from Norway's Minister of Fisheries in 2001-2005, Svein Ludvigsen, who shut down the fisheries crime hotline, arguing that it promoted "squealing" (Norw. angiveri).
} 
These two traditions - enabling legislation and corporatist management - reflect significant confidence in the competence and willingness of organised interests and civil servants to take responsibility for the common good. Although these traditions entail a risk of losing transparency and public control in fisheries management, it can be argued that they have certain advantages in terms of implementing conservation policies. When comparing the history of Norwegian implementation with that of the European Union, the reader may be struck by the extent to which Norwegian implementation of TACs has been treated as a question of administrative realisation of predefined political aims, rather than as a political tug-of-war regarding the political concerns that will rule the implementation agenda. It may be even more striking to observe the extent to which Norwegian industry organisations appear to have accepted resource conservation as the dominant goal to be pursued in the implementation of conservation policies. The state administration and the general public have continued to perceive the Norwegian Fishermen's Association and the sales organisations as reasonably responsible actors in the conservation discourse, and the loyalty of the sales organisations in fulfilling implementation tasks has never been questioned. Chapter 7 specifically addresses the mechanisms through which alternative political agendas feed into the process of implementing conservation policies, but it appears that Norwegian implementation of conservation policies has been comparatively resistant to such influences.

It can be argued that the responsibility for conservation decisions carried by core actors in the implementation process represents a strong disincentive for industry organisations to question political goals at the implementation stage. However, in order to explain the apparent robustness of conservation goals at the implementation level, it may be helpful to go a step further and consider what the institutionalisation of implementation as an administrative issue means in terms of the implementation "discourse". The concept of "discourse", which stems from Foucault's work $(1977,1999)$, refers to the often implicit normative boundaries of a given field of human interaction. These normative boundaries define the legitimate participants of a specific type of discussion. They also define, for example, the legitimate factors, the legitimate perspectives, and the legitimate values that can be applied to a discussion. It can be argued that the combination of enabling legislation and the specific form of Norwegian corporatist management has shaped the implementation discourse so that it has become relatively unreceptive to debate regarding political goals. The manifest tradition for keeping implementation strictly at the administrative level frames implementation as a purely administrative, as distinct from political, discourse. The Foucauldian perspective implies that, once framed as an administrative discourse, implementation is defined as a topic to be addressed among administrators complying with the norms of administration. Consequently, the question of implementation is framed within the mindset of the civil service. This frame greatly reduces the room for deliberation regarding the political aims to pursue when designing the implementation system. Actors and perspectives that are unsuitable to this frame, such as stakeholders 
suggesting a change in the fundamental goals to be pursued, will be disciplined or excluded from the discourse. Consequently, the implementation of conservation policies is likely to remain focused on conservation aims.

It can easily be imagined that the corporatist tradition potentially disturbs the administrative approach to implementation. However, although interaction between the industry and the state is a prominent feature of Norwegian fisheries management, this is not an equal relationship in terms of authority. The decisionmaking power lies with the state administration, while the industry organisations mainly serve as advisors. The corporatist management system is thus asymmetrical. This asymmetry means that the influence of the industry organisations depends on the extent to which they are included and taken seriously by the state administration. Consequently, the corporatist management model applied in Norwegian fisheries can be regarded not only as a channel for industry influence but as the state's "hostage" in disciplining the industry organisations: in order to remain influential, the industry organisations must adhere to the state administration's frame of discourse. Thereby, the asymmetrical relationship between the state administration and the industry organisations has restricted and shaped the state/industry dialogue in a manner that leaves little room for changing the primary political goals at the implementation stage.

In short, enabling legislation reflects and ensures that implementation is framed as a purely administrative discourse at state level, while asymmetrical corporatism has disciplined the industry organisations into adopting this frame of discourse. Consequently, the industry has emerged as a relatively loyal partner of the state administration in terms of keeping to the conservation goals in the implementation of conservation policies. The Norwegian implementation discourse is thus a result of the direct transfer of conservation goals from the bilateral and multilateral arenas in which they are negotiated to the level of national administration. By contrast, Chapters 5 and 6 illustrate the ability of alternative agendas to subvert conservation aims whenever implementation of international conservation goals becomes a matter of national politics.

\section{References}

Aardal, B. (1999). Velgere i 90-årene. Oslo: NKS-Forlaget.

Aardal, B., Valen, H., \& Opheim, I. (1999). Valgundersøkelsen 1997: Dokumentasjonsrapport. Oslo: Statistics Norway.

Apostle, R., Barret, G., Holm, P., Jentoft, S., Mazany, L., McCay, B., \& Mikalsen, K. (1998). Community, State, and Market on the North Atlantic Rim: Challenges to Modernity in the Fisheries. Toronto: University of Toronto Press.

Christensen, P., \& Hallenstvedt, A. (1990). På første hånd: Norges Råfisklag gjennom 50 år. Tromsø: Norges Råfisklag.

Christensen, P., \& Hallenstvedt, A. (2005). I kamp om havets verdier: Norges Fiskarlags historie. Trondheim: Norwegian Fishermen's Association.

Christensen, T., Egeberg, M., Larsen, H. O., Lægreid, P., \& Roness, P. G. (2007). Forvaltning og politikk. Oslo: Universitetsforlaget. 
Dahl, I. (2002). Uaktsom overtredelse av saltvannsfiskeloven §53. Lov og Rett nr. 9/10, 606-619.

David, P. A. (1985). Clyo and the Economics of qwerty. American Economic Review, 75(2), $332-337$.

Fiskaren (2006a). Leading article. June 72006.

Fiskaren (2006b). -Mildt sagt uenig med Fiskebåt. www.fiskaren.no. Accessed 19 January 2006.

Foucault, M., (1977). Discipline \& Punish: The Birth of the Prison. New York: Vintage Books.

Foucault, M. (1999). Diskursens orden. Oslo: Spartacus.

Gezelius, S. S. (2002a). Environmental Sustainability and Political Survival: A Comparative Analysis of the Cod Fisheries of Norway and Canada. Environmental Politics, 11(4), 63-82.

Gezelius, S. S. (2002b). Do Norms Count? State Regulation and Compliance in a Norwegian Fishing Community. Acta Sociologica, 45(4), 305-314.

Gezelius, S. S. (2003). Regulation and Compliance in the Atlantic Fisheries: State/Society Relations in the Management of Natural Resources. Dordrecht: Kluwer Academic publishers.

Gezelius, S. S. (2006). Monitoring Fishing Mortality: Compliance in Norwegian Offshore Fisheries. Marine Policy, 30(5), 462-469.

Gezelius, S. S. (2007). Three Paths from Law Enforcement to Compliance: Cases from the Fisheries. Human Organization, 66(4), 414-425.

Government of Norway (1917). Lov av 5. desember $1917 \mathrm{nr} .1$ om registrering og merking av fiskefartøyer (Act on Tagging and Registration of Fishing Vessels). Oslo: Stortinget.

Government of Norway (1937a). Innstilling fra komiteen til revisjon av lovene om sildefiskeriet. Oslo: Stortinget.

Government of Norway (1937b). Lov av 25. juni 1937 om sild- og brislingfiskeriene (Herring and Sprat Fisheries Act). Oslo: Stortinget.

Government of Norway (1938). Ot. prp. nr. 16. (1938). Om lov om fredning av saltvannsfisk (Act on Preservation of Salt Water Fish). Oslo: Ministry of trade.

Government of Norway (1951a). Lov av 14. desember 1951 nr. 3 om omsetning av råfisk (Raw Fish Act). Oslo: Stortinget.

Government of Norway (1951b). Lov av 20. april 1951 om fiske med trål (Act on Trawl Fisheries). Oslo: Stortinget.

Government of Norway (1954). Innstilling fra komiteen til samling og revisjon av fiskerilovene. Stortingsforhandlingene. Oslo: Stortinget.

Government of Norway (1955). Lov av 17. juni 1955 om saltvannsfiskeriene (Salt Water Fishing Act). Oslo: Stortinget.

Government of Norway (1956). Mellombels lov av 29. juni $1956 \mathrm{nr} .8$ om eigedomsretten til fiske- og fangstfarkostar. Oslo: Stortinget.

Government of Norway (1957a). Innstilling fra Torskefiskeutvalget. Oslo: Ministry of Fisheries.

Government of Norway (1957b). Lov om endringer i lov av 25. juni 1937 om sild- og brislingfiskeriene. Innstilling og vedtak. Oslo: Stortinget.

Government of Norway (1966). Lov 17. juni 1966 nr. 19 om forbud mot at utlendinger driver fiske m.v. i Norges territorialfarvann. Oslo: Stortinget.

Government of Norway (1970). Forskrifter om forbud mot fangst av makrell. 23. april. Oslo: Ministry of Fisheries.

Government of Norway (1971a). Ot. prp. nr. 22. Om lov om regulering av deltakelsen i fisket (Participation Act). Oslo: Ministry of fisheries.

Government of Norway (1971b). Forskrifter om fangstbegrensning av atlanto-skandisk sild. 8. jan. Oslo: Ministry of Fisheries.

Government of Norway (1971c). Lov av 11. juni1971 om rettledningstjenesten i fiskerinæringen. Oslo: Stortinget.

Government of Norway (1972a). Lov av 16. juni $1972 \mathrm{nr} 57$ om regulering av deltakelsen i fisket. Oslo: Stortinget. 
Government of Norway (1972b). Forskrifter om regulering av fiske etter lodde i 1972. 29. feb. Oslo: Ministry of Fisheries.

Government of Norway (1975a). Fiskeridirektoratet 75 år. Bergen: Directorate of Fisheries.

Government of Norway (1975b). NOU 1975: 50. Oppsynet med fiskeri- og petroleumsvirksomheten. Oslo: Universitetsforlaget.

Government of Norway (1975c). NOU 1975: 31. Kodifikasjon av fiskerilovgivningen. Oslo: Universitetsforlaget.

Government of Norway (1976a). Ot. prp. nr. 4 (1976-77). Om lov om Norges økonomiske sone. Oslo: Minister of ocean law and fisheries jurisdiction.

Government of Norway (1976b). Lov om Norges økonomiske sone. Oslo: Stortinget.

Government of Norway (1976c). Ot.prp. nr. 39 (1975-76). Lov om endring i lov av 16. juni 1972 nr. $57 \mathrm{om}$ regulering av deltagelsen i fisket. Oslo: Ministry of fisheries.

Government of Norway. (1976d). Vedtak til lov om endring i lov av 16. juni $1972 \mathrm{nr} .57 \mathrm{om}$ regulering av deltagelsen i fisket. Oslo: Stortinget.

Government of Norway (1977a). St. meld. nr. 18 (1977-78). Om langtidsplan for norsk fiskerinæring. Oslo: Ministry of fisheries.

Government of Norway (1977b). Forskrifter om regulering av fiske etter torsk nord for $62^{\circ} \mathrm{n}$. br. i 1977. Oslo: Ministry of fisheries.

Government of Norway (1978a). Rettledningstjenesten i fiskerinceringen. NOU 1978: 44. Oslo: Universitetsforlaget.

Government of Norway (1978b). St. meld. nr. 107 (1977-78). Om Fiskeridirektoratets kontrollverks organisering og oppgaver. Oslo: Ministry of Fisheries.

Government of Norway (1978c). Forskrifter om regulering av fiske etter makrell og lodde i 1978. Oslo: Ministry of Fisheries.

Government of Norway (1980). St. meld. nr. 43 (1979-80). Om rettledningstjenesten i fiskerinæringen. Oslo: Ministry of Fisheries.

Government of Norway (1981a). NOU 1981:3. Konsesjonsordninger i fiske. Oslo: Universitetsforlaget.

Government of Norway (1981b). Forskrifter om regulering av fisket etter norsk vårgytende sild $\mathrm{i}$ 1981. Oslo: Ministry of Fisheries.

Government of Norway (1982a). Lov om rettledningstjenesten i fiskerinæringen og om endringer i visse andre lover. Oslo: Stortinget.

Government of Norway (1982b). Ot. prp. nr. 85 (1981-82). Om lov om saltvannsfiske. Oslo: Ministry of fisheries.

Government of Norway (1982c). Forskrift om maskevidde, bifangst og minstemål m.m. i saltvannsfiske. Oslo: Ministry of Fisheries.

Government of Norway (1983a). St. meld. nr. 93. Om retningslinjer for fiskeripolitikken. Oslo: Ministry of fisheries.

Government of Norway (1983b). Lov om saltvannsfiske. Oslo: Stortinget.

Government of Norway (1984a). Forskrift om regulering av vinterloddefisket i Barentshavet i 1985. Oslo: Ministry of Fisheries.

Government of Norway (1984b). Forskrift om regulering av fisket etter norsk vårgytende sild $\mathrm{i}$ 1985. Oslo: Ministry of Fisheries.

Government of Norway (1984c). Forskrift om regulering av trålfisket etter torsk nord for $62^{\circ}$ n.br. i 1985. Oslo: Ministry of Fisheries.

Government of Norway (1985). Forskrift om regulering av fisket etter norsk vårgytende sild $\mathrm{i}$ 1986. Oslo: Ministry of Fisheries.

Government of Norway (1986a). Forskrift om maskevidde, bifangst og minstemål m.m. i saltvannsfiske. Oslo: Ministry of Fisheries.

Government of Norway (1986b). Forskrift om trålfiske etter torsk nord for $62^{\circ}$ n.br. i 1987. Oslo: Ministry of Fisheries.

Government of Norway (1986c). Forskrift om oppgaveplikt for fiske og fangstfartøy. Oslo: Ministry of fisheries. 
Government of Norway (1987a). Forskrift om forbud mot utkast av torsk og hyse i Norges økonomiske sone utenfor det norske fastland. Oslo: Ministry of Fisheries.

Government of Norway (1987b). Forskrift om regulering av fisket etter makrell i Norges økonomiske sone sør for $62^{\circ}$ n.br., i EF-sonen i Nordsjpøen og i Skagerak i 1988. Oslo Ministry of Fisheries.

Government of Norway (1987c). Forskrift om regulering av fisket etter makrell i Norges økonomiske sone nord for $62^{\circ}$ n.br., i internasjonalt farvann og i færøysk sone i 1988. Oslo Ministry of Fisheries.

Government of Norway (1988a). Ot. prp. nr. 77 (1987-88). Om lov om endringer i lov 3. juni $1983 \mathrm{nr} .40 \mathrm{om}$ lov om saltvannsfiske m.v. og i visse andre lover. Oslo: Ministry of fisheries.

Government of Norway. (1988b). Forskrift om endring av forskrift om maskevidde, bifangst og minstemål m.m. i saltvannsfiske. Oslo: Ministry of Fisheries.

Government of Norway (1988c). Kontroll av reguleringsbestemmelser. Forslag fra arbeidsgruppen til tiltak og revisjon av lover og forskrifter. Notat. Bergen: Directorate of fisheries.

Government of Norway (1988d). Besl.O. nr. 36. Vedtak til lov om endringer i lov 3. juni 1983 nr. 40 om lov om saltvannsfiske m.v. og i visse andre lover. Oslo: Stortinget.

Government of Norway (1989a). Ot.prp. nr. 81 (1988-89) Om lov om endringer i lov av 3. juni $1983 \mathrm{nr} .40 \mathrm{om}$ saltvannsfiske m.v. og i lov 14. desember $1951 \mathrm{nr} .3 \mathrm{om}$ omsetning av råfisk. Oslo: Ministry of fisheries.

Government of Norway (1989b). Forskrift om maskevidde, bifangst, fredningstid og minstemål m.v. ved fangst av fisk og sild. Oslo: Ministry of Fisheries.

Government of Norway (1989c). Besl. O. nr. 2. Vedtak til lov om endringer i lov av 3. juni 1983 nr. 40 om saltvannsfiske m.v. og i lov av 14. desember $1951 \mathrm{nr} .3 \mathrm{om}$ omsetning av råfisk. Oslo: Stortinget.

Government of Norway (1989d). Forskrift om fangstrapportering m.m. for fartøyer som tilvirker egen fangst av sild og makrell, 19. sept. Nr. 944. Oslo: Ministry of fisheries.

Government of Norway (1989e). Forskrift om fangstrapportering m.m. for torsketrålere. 16. jan. Nr. 16. Oslo: Ministry of fisheries.

Government of Norway (1991). Salgsorganisasjonenes kontrollplikt. Instruks 20. feb. Oslo: Ministry of fisheries.

Government of Norway (1992). St. meld. nr. 58 Om struktur- og reguleringspolitikk overfor fiskeflåten. Oslo: Ministry of fisheries.

Government of Norway (1993a). Ot. prp. Nr. 90 (1992-93). Om lov om prisregulering ved import av fiskevarer m.v. Oslo: Ministry of fisheries.

Government of Norway (1993b). Forskrift om oppgaveplikt for fiske- og fangstfartøy. Oslo: Ministry of Fisheries.

Government of Norway (1993c). Instruks for føring av fangstdagbok. Bergen: Directorate of Fisheries.

Government of Norway (1993d). Forskrift om forbud mot landing av fisk andre særskilte tiltak mot ulovlig, rapporter og uregulert fiske. Oslo: Ministry of Fisheries.

Government of Norway (1995a). St. meld. nr. 49 (1994-95). Om dei årlege fiskeriavtalene Noreg inngår med andre land. Oslo: Ministry of fisheries.

Government of Norway (1995b). Forskrift om endring av forskrift om sluttseddel/bryggeseddel og mottaksjournal, 13. mars Nr. 249. Oslo: Ministry of fisheries.

Government of Norway (1996a). Forskrift om endring av forskrift om sluttseddel/bryggeseddel og mottaksjournal, 17. okt. Nr. 988. Oslo: Ministry of fisheries.

Government of Norway (1996b). Forskrift om endring i forskrift om fangstrapportering m.m. for torsketrålere som kan tilvirke fangst om bord. 7. nov. Nr. 1019. Oslo: Ministry of fisheries.

Government of Norway (1996c). Forskrift om endring i forskrift om fangstrapportering m.m. for fartøy som kan tilvirke fangst av sild og makrell. 7. nov. Nr. 1020. Oslo: Ministry of fisheries.

Government of Norway (1997). Instruks for Reguleringsrådet. Oslo: Ministry of fisheries. 
Government of Norway (1998a). Ot. prp. nr 58 (1997-98) Om lov om endring i lov 3 juni 1983 nr. 40 om saltvannsfiske m.v. Oslo: Ministry of fisheries.

Government of Norway (1998b). Lov om endringar i lov 3 juni $1983 \mathrm{nr} .40$ om saltvannsfiske m.v., 17 juli Lov nr. 57. Oslo: Ministry of fisheries.

Government of Norway (1998c). Norwegian Black List. Bergen: Directorate of Fisheries. www.fiskeridir.no.

Government of Norway (1999a). Forskrift om satelittbasert overvåking av fiske- og fangstfartøys aktivitet, 7. april Nr. 387. Oslo: Ministry of Fisheries.

Government of Norway (1999b). Forskrift om registrering og rapportering ved fiske i farvann utenfor noen stats fiskerijurisdiksjon, 30. juni Nr. 1499. Bergen: Directorate of fisheries.

Government of Norway (1999c). Forskrift om endring i forskrift om inndragning av fangst og anvendelse av inndratte midler, 17. mars Nr. 362. Oslo: Ministry of fisheries.

Government of Norway (1999d). Lov om retten til å delta i fiske og fangst (deltakerloven), 26. mars nr. 15. Oslo: Stortinget.

Government of Norway (2001a). Ot. prp. nr. 92 (2000-2001) Om lov om endringer i lov 3. juni $1983 \mathrm{nr} .40 \mathrm{om}$ saltvanssfiske m.v. og lov 14 desember $1951 \mathrm{nr} .3 \mathrm{om}$ omsetning av råfisk (kontrolltiltak). Oslo: Ministry of fisheries.

Government of Norway (2001b). Lov om endringer i lov 3. juni $1983 \mathrm{nr} .40$ om saltvanssfiske m.v. og lov 14 desember $1951 \mathrm{nr}$. 3 om omsetning av råfisk (kontrolltiltak). Oslo: Stortinget.

Government of Norway (2003a). St. meld. nr. 43 (2002-2003). Om dei fiskeriavtalene Noreg har inngått med andre land for 2003 og fisket etter avtalene i 2001 og 2002. Oslo: Ministry of fisheries.

Government of Norway (2003b). Forskrift om opplysningsplikt ved landing og omsetning av fisk. Bergen: Directorate of fisheries.

Government of Norway (2003c). Report on the Norwegian system of sanctions. In Working group of control experts on methods and procedures for weighing pelagic fish, Weighing and inspection of landings of pelagic fish - including the pilot project. Bergen: Directorate of Fisheries.

Government of Norway (2003d). Ot. prp. nr 35 (2002-2003) Om lov om norges territorialfarvann og tilstøtende sone. Oslo: Ministry of foreign affairs.

Government of Norway (2004a). Salgsorganisasjonenes kontrollplikt J-117-2004. Bergen; Directorate of Fisheries.

Government of Norway (2004b). Kommisjonen for tiltak mot utkast av fisk - Rapport med anbefalinger. Bergen: Directorate of Fisheries.

Government of Norway (2004c). Forskrift om utøvelse av fisket i sjøen, 2004-12-22 nr 1878. Oslo: Ministry of fisheries.

Government of Norway (2005a). St. meld. nr. 39 (2004-2005). Om dei fiskeriavtalene Noreg har inngått med andre land for 2005 og fisket etter avtalene i 2003 og 2004. Oslo: Ministry of fisheries.

Government of Norway (2005b). Forskrift om rapportering av fangst for norske fartøy. 16. feb nr. 151. Oslo: Ministry of fisheries and coastal affairs.

Government of Norway (2005c). Lov om forvaltning av viltlevende ressurser : Havressursloven. NOU 2005: 10. Oslo: Statens forvaltningstjeneste.

Government of Norway (2006a). Prosjekt salgslag/Fiskeridirektorat: En kartlegging av salgslagenes og Fiskeridirektoratets virke på de områder en har felles ansvar for ressurskontrollen. Delrapport A. Bergen: Directorate of Fisheries.

Government of Norway (2006b). Ot.prp. nr. 98 (2005-2006) Om lov om endringer i lov 17. juni $1966 \mathrm{nr} .19 \mathrm{om}$ forbud mot at utlendinger driver fiske m.m. i Norges territorialfarvann og i lov 3. juni $1983 \mathrm{nr} .40$ om saltvannsfiske m.v. Oslo: Ministry of Fisheries.

Government of Norway (2007a). St. meld. nr. 32 (2006-2007). Om dei fiskeriavtalene Noreg har inngått med andre land for 2007 og fisket etter avtalene i 2005 og 2006. Oslo: Ministry of fisheries. 
Government of Norway (2007b). IUU-liste på fiskeridir.no. Press release 30 April 2007. Bergen: Directorate of Fisheries. www.fiskeridir.no.

Government of Norway (2007c). Informasjon om gjennomføringen av havnestatskontroll i Norge. Bergen: Directorate of Fisheries.

Government of Norway (2007d). Forskrift om endring av forskrift om regulering av fisket etter torsk, hyse og sei nord for $62^{\circ} \mathrm{N}$ i 2007 . Bergen: Directorate of fisheries.

Government of Norway (2007e). Ot. prp. nr. 20 (2007-2008) Om lov om forvaltning av viltlevende marine ressurser (Havressurslova (Act on the Management of Wild Marine Living Resources)). Oslo: Ministry of Fisheries and Coastal Affairs.

Hallenstvedt, A. (1995). Organisational Structure Norwegian Fisheries. Notat nr. 5. Bodø: NORUT.

Hallenstvedt, A., \& Dynna, B. (1976). Fra Skårunge Til Høvedsmann: Med Norges Fiskarlag gjennom 50 år. Trondheim: Norwegian Fishermen's Association.

Hallenstvedt, A. (1993). Ressurskontroll i norsk fiskeriforvaltning. In Ressursforvaltning og kontroll - kontrollpolitikk og virkemidler $i$ de nordiske land og $i$ EF, edited by Abraham Hallenstvedt. Nordiske Seminar- og Arbeidsrapporter 1993:583 (pp. 119-146). Copenhagen: Nordic Council of Ministers.

Holm, P. (1996). Kan torsken temmes? Moderniseringsprosesser i fiskerinæringa 1935-1995. in Det nye Nord-Norge: Avhengighet og modernisering $i$ nord, edited by Erik Oddvar Eriksen. (pp. 109-142) Bergen: Fagbokforlaget.

Hersoug, B. (2005). Closing the Commons: Norwegian Fisheries Management from Open Access to Private Property. The Hague: Eburon.

Hoel, A. H., Jentoft, S., \& Mikalsen, K. H. (1991). Problems of User-Group Participation in Norwegian Fisheries Management. Occasional Papers no A 56, Tromsø: Institute of Social Sciences, University of Tromsø.

ICES (International Council for the Exploration of the Sea) (2007). ICES Advice 2003, Book 3. Copenhagen: ICES.

Jentoft, S. (1991). Hengende snøre: Fiskerikrisen og framtiden på kysten. Oslo: Ad Notam forlag.

Johannesen, A., \& Misje, M. (2002). “Rott jer sammen” - Norges Sildesalgslag 1927-2002. Bergen: The Norwegian Sales Organization for Pelagic Fish.

Lindblom, C. (1959). The science of muddling through. Public Administration Review, 19(2), 79-88.

Miller, A. M., \& Listhaug, O. (1998). "Policy Preferences and Political Distrust: A Comparison of Norway, Sweden and the United States." Scandinavian Political Studies 21, 161-187.

NEAFC (North East Atlantic Fisheries Commission) (1971). Report of the ninth meeting. London: NEAFC.

NEAFC (North East Atlantic Fisheries Commission) (1974). Report of the Special Meetings. London: NEAFC.

NEAFC (North East Atlantic Fisheries Commission) (2007). Scheme of Control and Enforcement. London: NEAFC.

Nordstrand, L. (2000). Fiskeridirektøren melder: Fiskeridirektoratet 1900-1975. Bergen: Directorate of fisheries.

NRK (2006). Overfiske ødelegger torskebestanden. 14 November 2006. www.nrk.no.

Rozwadowski, H. M. (2002). The Sea Knows No Boundaries: A Century of Marine Science under ICES. Copenhagen: ICES.

Sagdahl, B. K. (1992). Ressursforvaltning og legitimitetsproblemer: En studie av styringsproblemer ved forvaltning av norsk-arktisk torsk. Bodø: Nordland Research Institute.

Seip, J. A. (1997). Utsikt over Norges historie. Oslo: Gyldendal.

Sen, S. (1997). The evolution of high-seas fisheries management in the north-east Atlantic. Ocean \& Coastal Management, 35(2-3), 85-100. 
Sunnanå, K. (1964). Kyststatens problemer i forbindelse med internasjonale fiskerireguleringer. In Foredrag under den 9. nordiske fiskerikonferansen, Reykjavik 22.-26.6 1964 (pp. 22-34).

Sørensen, Ø. (1998a). Når ble nordmenn norske? In Ø. Sørensen (ed.), Jakten på det norske Perspektiver på utviklingen av en norsk nasjonal identitet på 1800-tallet (pp. 11-16). Oslo: Ad Notam Gyldendal.

Sørensen, Ø. (1998b). Hegemonikamp om det norske - Elitenes nasjonsbyggingsprosjekter 1770-1945. In Ø. Sørensen (ed.), Jakten på det norske - Perspektiver på utviklingen av en norsk nasjonal identitet på 1800-tallet (pp. 17-50). Oslo: Ad Notam Gyldendal..

UN (United Nations) (1995). Agreement for the implementation of the provisions of the United nations Convention on the Law of the Sea of 10 December 1982 relating to the conservation and management of straddling fish sticks and highly migratory fish stocks. New York: United Nations. 